\title{
Labour flexibility and wages: lessons from Spain
}

Samuel Bentolila and Juan J. Dolado

CEMFI, and Banco de España, CEMFI and CEPR

\section{Introduction}

Temporary employment is gaining ground in Europe. While in 1983 only $4 \%$ of employees in the EC held temporary jobs, in $199110 \%$ did. The pattern has not been uniform across Europe, however, with moderate increases in various countries and the most marked in France and Spain. The trend rise of temporary employment is linked to the low rate of job creation in EC countries since the mid-1970s. A widespread opinion among entrepreneurs and policy-makers has been that labour market flexibility had to be increased in order to cure this European malaise, sometimes diagnosed as Eurosclerosis. This has prompted the enactment of numerous changes in employment security legislation. Sometimes affecting all workers, the movement towards increased flexibility has mostly attempted to promote atypical (i.e. part-time and temporary) labour contracts. These contracts were expected to provide firms with the additional flexibility they needed to cope with higher demand uncertainty, accelerated technical change, fiercer international competition, etc., so that they would be willing to create new jobs again.

Support for this line of reasoning stemmed mainly from informal comparisons with the US labour market. In stark contrast with Europe, between 1973 and 1991, US employment had grown at an average rate of $1.7 \%$, almost six times the corresponding EC rate. It has often been argued that the main reason for this relatively favourable evolution lies with the markedly less regulated nature of the US labour market. Hence,

We are grateful to our discussants, W. Franz and C. Pissarides, and to M. Arellano, J.F. Jimeno, V. Norman and S. Nickell for helpful comments. We also wish to thank J. Sicilia for excellent research assistance, and S. Cardenal, P. García-Perea, I. Hernando, L. Freyseon, C. Mazón, J. Vallés, and the staff of the Central de Balances del Banco de Espana for help with data collection. 
flexibility was taken to be a key issue. However, in spite of the introduction of flexibility-enhancing measures, job creation in EC countries has not been particularly remarkable in the 1980 s, and unemployment remains stubbornly high. Had the benefits of labour market flexibility been overemphasised or, on the contrary, did the measures taken not go far enough?

In order to address these issues, we start by bringing attention to the flip side of the divergence in European and US employment paths. Real wages have grown in Europe by $1.7 \%$ per annum during the 1970s and 1980 s, but only by $0.4 \%$ in the US. Apart from raising employers' willingness to hire, labour market deregulation was probably expected to yield higher real wage flexibility as well, something which has apparently not happened. Focusing on this issue, the main argument of this paper is that the measures taken have not produced the desired results partly because most of them increased flexibility at the margin, without affecting the core of permanent employees.

The reason why it matters whether flexibility affects all workers or only those at the margin is as follows. Wage setting in Europe is widely seen today as dominated by insider employees, i.e., incumbent workers whose jobs are protected either by substantial labour turnover costs or by the possession of specific skills which are needed in the production process. ${ }^{1}$ It is usually considered that the insiders are those currently employed, who are seen as maximizing the rents that they manage to extract from employers through wage bargaining. Insiders are believed to conduct the bargain with only their own employment prospects in mind, disregarding the interests of unemployed outsiders.

By reducing labour turnover costs, legal changes encouraging the use of temporary contracts should have reduced the power of insiders in the wage bargain. We will argue that, on the contrary, they may have increased it, at least in those countries where protection for permanent employees is still high. The reason is that those changes have separated the work-force into two groups: the insiders, and a new group of temporary employees with low firing costs, whose attachment to their employer is fragile, precisely because their role is to bear the brunt of employment adjustments. This fragility should naturally lead to the wage bargain being mostly in the hands of the core of permanent, full-time employees. And it may also lead to the interests of flexible workers carrying lower weight in the wage bargain than those of permanent employees. If both conditions hold, then insiders may be able to obtain higher wages,

\footnotetext{
1 A large body of literature has followed the insider-outsider approach started in a few articles by Lindbeck and Snower (1988b) and given a dynamic form by Blanchard and Summers (1986).
} 
since the presence of a buffer of flexible employees lowers the likelihood that insiders will lose their jobs.

To make our point, we analyse in detail an extreme case: the Spanish labour market. Spain merits specific examination for two reasons. First, since the early 1970s, this country has had the worst unemployment record in Europe (the current unemployment rate is $23 \%$ !). And second, in 1975 it inherited from Franco's regime a very rigid labour market. Both features prompted the government to introduce, in 1984, fixedterm labour contracts with low firing costs, for all activities, temporary or not. This scheme has expanded very rapidly and, as a result, it now comprises one-third of all employees, by far the highest proportion in the EC. These contracts have had several important effects, like a marked increase in labour turnover, but they have provided only shortlived wage moderation. We believe that this perverse effect illustrates how insiders can benefit from flexibility at the margin. We suspect that the same phenomenon may also be occurring in other EC countries, like France, where temporary employment has been rising. It could well be kept in mind in those countries currently considering whether to follow the Spanish strategy of setting up an extensive two-tier system without reforming the protection afforded to permanent staff.

The paper proceeds in four steps. Section 2 presents an overview of the changes in labour contracts that have taken place in Europe since the mid-1970s, devoting particular attention to the case of Spain. Then, in Section 3, we amend the standard framework of insider wage-setting to consider two groups of workers, with permanent and temporary contracts. We show that when only the insiders bargain with the firm two main effects occur: insiders' wage growth is enhanced by a buffer effect because dismissals provoked by excessive wage settlements affect temporary workers first; and the bargaining power of permanent workers is modified, with ambiguous implications for wage growth. If the two types of workers have different wages (which seems to be the case in Spain), there is also a composition effect on average wage growth. Section 4 confronts the theory with the data. A large sample of private Spanish manufacturing firms over 1985-88 confirms that the interests of temporary workers are basically disregarded in wage bargains, and that each percentage point of increase in temporary employment could imply up to one-third of one percent increase in wages of permanent employees. Section 5 investigates whether these results hold for countries with a lower rate of temporary employment. A sample consisting of 13 manufacturing industries in Denmark, France, West Germany and the United Kingdom over the period 1983-91 provides results less tight than those for spain, but still roughly favourable to our hypothesis. 
The conclusions that we draw from these results are presented in Section 6.

\section{Temporary employment in Europe}

\subsection{Changes in European labour markets}

2.1.1 Frequency of temporary employment. Traditionally, the typical European job has been full-time and of indefinite duration. However, such a job is not as prevalent as it used to be. So-called atypical employment forms have been growing in importance. This includes part-time and temporary employment, as well as employment for home production, selfemployment, and even the underground economy. Although organizations like the OECD often lump together all these forms of employment, we confine our study to temporary work which, as we will show below, is the one that matters most for labour flexibility considerations.

In Table 1 temporary employment includes both employment through a temporary work agency (where a worker is contracted out to a firm for a specified period of time) and direct fixed-term contracts. Since separate data on each of these two types is not available in official statistics, hereafter the term temporary employment will refer to the two types combined. The figures presented in the table correspond to 1983 (or the first available year) and 1991. Temporary employment has increased sharply in France and Spain, and moderately in Ireland, Luxembourg, and the Netherlands, while it has been stable or slightly declining in the remaining EC countries shown. Outside the EC, it has increased slightly in Finland and Japan, and declined in Australia and Turkey. ${ }^{2}$

2.1.2 Reasons for using temporary work. A clue is given by Table 2. In a subset of EC countries it appears that temporary employment is more prevalent among women (except in Greece) and especially among youths. This form of employment is also more intensively used in services than in manufacturing. Finally, unskilled and semi-skilled workers are normally over-represented among those in temporary jobs (See, e.g., Buchtemann and Quack, 1989, for Germany).

From the labour supply side, the table might be read as suggesting that temporary employment may be chosen by workers with a preference for an unstable attachment to the labour force, like women and youths. This

\footnotetext{
2 Since temporary employment shows some cyclical variability, the dates chosen for the comparison affect the sign of the change in several countries. Note also that definitions of temporary employment differ by country (see OECD, 1993).
} 
Table 1. Temporary employment in selected OECD countries (\%)

\begin{tabular}{lrr}
\hline & 1983 & 1991 \\
\hline European Community: & & \\
Belgium & 5.4 & 5.1 \\
Denmark (a) & 12.5 & 11.9 \\
France & 3.3 & 10.1 \\
W. Germany (a) & 9.9 & 9.3 \\
Greece & 16.3 & 14.7 \\
Ireland & 6.2 & 8.3 \\
Italy & 6.6 & 5.4 \\
Luxembourg & 3.2 & 3.3 \\
Netherlands & 5.8 & 7.7 \\
Portugal (b) & 16.9 & 16.5 \\
Spain (c) & 11.3 & 32.2 \\
United Kingdom & 5.5 & 5.3 \\
& & \\
Non-EC: & & 19.7 \\
Australia (b) & & 13.1 \\
Finland & 21.1 & 10.5 \\
Japan & 11.1 & 6.6 \\
Turkey (d) & 10.3 & 7.2 \\
\hline \hline
\end{tabular}

Source: Eurostat (1992), OECD (1993) and, for Spain in 1985, Segura et al. (1991).

Notes: Data are percentages of the number employees. The year in the first column is 1983 except for the following cases: (a) 1984, (b) 1987, (c) 1985, and (d) 1988.

Table 2. Composition of temporary employment in selected EC countries (\%), 1991. (a)

\begin{tabular}{|c|c|c|c|c|c|c|}
\hline & \multicolumn{3}{|c|}{ Age } & \multirow{2}{*}{$\frac{\text { Sex }}{\text { Females }}$} & \multicolumn{2}{|c|}{ Sectors } \\
\hline & $15-24^{(b)}$ & $25-54$ & $55-64$ & & Manuf. & Serv. \\
\hline Denmark & $\begin{array}{c}56.6 \\
(24.5)\end{array}$ & $\begin{array}{c}39.7 \\
(67.5)\end{array}$ & $\begin{array}{c}3.8 \\
(8.0)\end{array}$ & $\begin{array}{c}52.1 \\
(48.6)\end{array}$ & 8.1 & 10.7 \\
\hline France & $\begin{array}{c}44.5 \\
(15.8)\end{array}$ & $\begin{array}{c}53.4 \\
(78.3)\end{array}$ & $\begin{array}{c}2.1 \\
(5.9)\end{array}$ & $\begin{array}{c}52.6 \\
(45.2)\end{array}$ & 8.0 & 8.4 \\
\hline W. Germany & $\begin{array}{c}58.3 \\
(20.6)\end{array}$ & $\begin{array}{c}39.0 \\
(70.8)\end{array}$ & $\begin{array}{c}2.7 \\
(8.6)\end{array}$ & $\begin{array}{c}45.1 \\
(41.3)\end{array}$ & 6.8 & 9.0 \\
\hline Greece & $\begin{array}{c}25.8 \\
(15.6)\end{array}$ & $\begin{array}{c}66.7 \\
(76.4)\end{array}$ & $\begin{array}{c}7.5 \\
(8.1)\end{array}$ & $\begin{array}{c}34.4 \\
(34.7)\end{array}$ & 12.0 & 13.3 \\
\hline Portugal & $\begin{array}{c}49.2 \\
(25.6)\end{array}$ & $\begin{array}{c}47.7 \\
(66.6)\end{array}$ & $\begin{array}{c}3.1 \\
(7.8)\end{array}$ & $\begin{array}{c}47.6 \\
(42.8)\end{array}$ & 14.0 & 17.6 \\
\hline Spain & $\begin{array}{c}40.8 \\
(24.1)\end{array}$ & $\begin{array}{c}55.3 \\
(66.9)\end{array}$ & $\begin{array}{c}3.9 \\
(8.9)\end{array}$ & $\begin{array}{c}38.3 \\
(33.8)\end{array}$ & 27.5 & 32.3 \\
\hline United Kingdom & $\begin{array}{c}39.1 \\
(20.4)\end{array}$ & $\begin{array}{c}52.1 \\
(68.9)\end{array}$ & $\begin{array}{c}8.8 \\
(10.6)\end{array}$ & $\begin{array}{c}62.5 \\
(47.6)\end{array}$ & 2.6 & 5.8 \\
\hline
\end{tabular}

Source: Age and sex: OECD (1993). Sectors: Eurostat (1992).

Notes: (a) Data are percentages of each group in the total number of employees of that type. Figures in parenthesis refer to the composition of all employees. (b) The data for Greece and Portugal refer to persons aged 14-24, while for France and the UK the data refer to persons aged $16-24$. 
Table 3. Regulations on fixed-term contracts in selected EC countries (1990)

\begin{tabular}{|c|c|c|c|c|c|c|}
\hline $\begin{array}{l}\text { Degree of government } \\
\text { regulation }\end{array}$ & $\begin{array}{l}\text { Contract } \\
\text { regulations (a) }\end{array}$ & Restrictions (b) & $\begin{array}{c}\text { Maximum } \\
\text { duration (c) }\end{array}$ & Renewable (d) & $\begin{array}{l}\text { Temmination } \\
\text { benefits (e) }\end{array}$ & $\begin{array}{l}\text { Conversion to } \\
\text { permanent (f) }\end{array}$ \\
\hline \multicolumn{7}{|l|}{ Minimum } \\
\hline Denmark & $\mathbf{N}$ & $\mathbf{N}$ & $\mathbf{N}$ & $\mathbf{Y}$ & $\mathbf{N}$ & $\mathbf{N}$ \\
\hline United Kingdom & $\mathbf{N}$ & $\mathbf{N}$ & $\mathbf{N}$ & $\mathbf{Y}$ & $\mathbf{N}$ & $\mathbf{Y}$ \\
\hline \multicolumn{7}{|l|}{ Moderate } \\
\hline Germany & $\mathbf{Y}$ & $\mathbf{Y}$ & 18 & $\mathbf{N}$ & $\mathbf{N}$ & $\mathbf{N}$ \\
\hline Greece & $\mathbf{Y}$ & $\mathbf{Y}$ & $\mathbf{N}$ & 2 & $\mathbf{N}$ & $\mathbf{Y}$ \\
\hline \multicolumn{7}{|l|}{ Severe } \\
\hline France & $\mathbf{Y}$ & $\mathbf{Y}$ & 24 & 2 & $\mathbf{Y}$ & $\mathbf{Y}$ \\
\hline Portugal & $\mathbf{Y}$ & $\mathbf{Y}$ & 36 & 2 & $\mathbf{Y}$ & Y \\
\hline Spain & $\mathbf{Y}$ & $\mathbf{Y}$ & 36 & $\mathbf{Y}$ & $\mathbf{Y}$ & $\mathbf{Y}$ \\
\hline
\end{tabular}

Source: OECD (1993, p. 19).

Notes: ' $Y$ denotes required and ' $N$ ' denotes not required.

(a) Legislation regulating the use of fixed-term contracts.

(b) Specific circumstances restricting the use of a contract.

(c) The maximum duration of a contract in months, including renewals. $\mathrm{N}$ indicates no maximum duration.

(d) Possibility of renewal and, if applicable, the number of times a contract may be renewed.

(e) Whether an indemnity is paid to the employee at the end of the contract.

(f) Possibility of becoming a permanent contract. 


\begin{tabular}{lccc}
\hline & $\begin{array}{c}\text { Written } \\
\text { notice }\end{array}$ & $\begin{array}{c}\text { Written } \\
\text { statement } \\
\text { of reason }\end{array}$ & $\begin{array}{c}\text { Consultation } \\
\text { with employee } \\
\text { reresentation }\end{array}$ \\
\hline Denmark & $\mathbf{N}$ & $\mathbf{N}$ & $\mathbf{N}$ \\
France & $\mathbf{Y}$ & $\mathbf{N}$ & $\mathbf{N}$ \\
Germany & $\mathbf{N}$ & $\mathbf{N}$ & $\mathbf{N}$ \\
Greece & $\mathbf{Y}$ & $\mathbf{N}$ & $\mathbf{Y}$ \\
Portugal & $\mathbf{Y}$ & $\mathbf{Y}$ & $\mathbf{Y}$ \\
Spain & $\mathbf{Y}$ & $\mathrm{Y}$ & $\mathbf{N}$ \\
United Kingdom & $\mathbf{N}$ & $\mathrm{Y}$ & \\
\hline \hline
\end{tabular}

Source: OECD (1993).

Note: ' $\mathrm{Y}$ denotes required and ' $\mathrm{N}$ ' not required.

seems to be more true in some countries than in others, where workers would rather hold a permanent job. In a 1991 survey, the fractions of workers who said they held a temporary job because they could not find a permanent one were: $28 \%$ in the UK, $38 \%$ in Denmark, $68 \%$ in Portugal, 77\% in Greece, and $89 \%$ in Spain (OECD, 1993).

These figures indicate that, especially in the latter countries, the preference for temporary work is in fact induced by the labour demand side. Traditional reasons for firms wanting to hire on a fixed-term basis are the temporary or seasonal nature of the production activity (e.g. agriculture, construction or tourism) and the need to cover for short-term absence of permanent employees (e.g. sickness or military service). This is why in countries where activities of this kind are important (e.g. Greece, Portugal or Spain) temporary employment is more prevalent.

2.1.3 Regulations. The use of temporary work also depends on how it is regulated. A summary of the regulations on fixed-term contracts appears in Table $3^{3}$ for a sample of EC countries with minimum, moderate and severe regulation. Countries with the most stringent regulations, like France, Portugal and Spain, are also those with the highest percentages of temporary employment. This apparently counter-intuitive fact is not so surprising when it is realised that these countries are also the ones with the most stringent limitations on the dismissal of permanent employees.

Ever since the first oil price shock, employers have often expressed the view that, in a context of higher demand and cost uncertainties, pervasive

Similar information on the regulation of temporary employment through temporary work agencies. not reproduced here, can be found in OECD (1993). 
regulations on hiring and firing constituted an obstable to job creation in Europe. Information on the stringency of such regulations - authorisation procedures and statutory severance payments for fair and unfair dismissals of individual workers - is presented by Tables 4 and 5 for the same sample of EC countries as in Table 3. These provisions are less severe in the UK and Denmark than in the remaining countries.

Collective redundancies are also regulated. In all EC countries, firms are required to consult in advance with employee representatives and to give advance notice to labour market authorities. However, in Greece, the Netherlands, Portugal and Spain they are also required to obtain prior administrative authorisation. This used to be the case in France until 1986: even though Tables 4 and 5 do not make France look highly regulated, the authorities have a long tradition of active intervention. Just to give a recent example, as of January 1993, French firms with 50 or more workers wanting to dismiss more than 9 workers are required to have a plan for their redeployment approved by the authorities (otherwise the dismissals cannot take place). ${ }^{4}$

2.1.4 Evolution. In response to complaints by entrepreneurs, many European governments have adapted their employment security legislations over the 1980s. They did so explicitly, by reducing notice periods and severance pay amounts, and by removing the requirement of administrative approval of dismissals (OECD, 1993, p. 98). However, as stressed by Saint-Paul (1993), radical changes in legal arrangements limiting firms' freedom of choice over employment tend to be politically difficult to introduce, since they clash with the interests of those with permanent contracts, who are still a majority. Thus, some countries have rather favoured the introduction of changes which do not affect the employment security of permanent employees. In this area we can list: the easing of the ability of firms to use temporary lay-offs and short-time work, the lowering of the benefit coverage of selected groups of workers, typically older ones, and the encouragement of atypical work arrangements, particularly temporary work.

Fixed-term contracts provide increased flexibility essentially by lowering firing costs (most notably, severance pay). European governments (for example, Spain and France in 1984 and 1985, respectively) have encouraged the use of such contracts in two main ways. First, by reducing social security contributions for youth training under temporary contracts. Second, by relaxing the restrictions on the use of fixed-term

\footnotetext{
4 The same rule will probably apply in Spain starting in 1994.
} 
Table 5. Legisiated individual severance pay for fair and unfair dismissals in selected EC countries, $1991^{(a)}$

\begin{tabular}{|c|c|c|c|c|c|c|c|c|c|}
\hline & \multirow{3}{*}{ Year (b) } & \multicolumn{4}{|c|}{ Fair dismissal } & \multicolumn{4}{|c|}{ Unfair dismissal } \\
\hline & & \multicolumn{2}{|c|}{ Blue collar } & \multicolumn{2}{|c|}{ White collar } & \multicolumn{2}{|c|}{ Blue collar } & \multicolumn{2}{|c|}{ White collar } \\
\hline & & Minimum & Maximum & Minimum & Maximum & Minimum & Maximum & Minimum & Maximum \\
\hline Denmark & 1978 & 0 & 0 & 1 & 3 & $\cdots$ & 9.75 & . & 9.75 \\
\hline France & 1982 & 0 & 1.5 & 0 & 1.5 & 6 & $\ldots$ & 6 & $\ldots$ \\
\hline Germany & 1969 & 0 & 0 & 0 & 0 & 1 & 18 & 1 & 18 \\
\hline Greece & 1955 & 0.17 & 2.5 & 1 & 24 & . & 48 & $\ldots$ & 48 \\
\hline Portugal & 1989 & 1 & 15 & 1 & 15 & 1 & 15 & 1 & 15 \\
\hline Spain & 1984 & 0.7 & 12 & 0.7 & 12 & 0 & 42 & 0 & 42 \\
\hline United Kingdom & 1984 & 0 & 6 & 0 & 6 & . & 6 & . & 6 \\
\hline
\end{tabular}

Source: OECD (1993).

Notes: . . Data not available. (a) Months of pay. (b) Year when the legislation was passed. 
contracts in non-temporary activities (the so called non-causal contracts) thereby increasing the degree of substitution between permanent and temporary jobs.

How important are these new reasons (flexibility) in comparison with the traditional ones (type of activity)? On average, the latter are still dominant. In a survey carried out in eight European countries in 1989-90, weighting firms by employment, $36 \%$ of employers quoted both types of reasons, $39 \%$ only traditional reasons and $17 \%$ only new reasons. Traditional reasons are more prevalent in countries like Italy or the UK than in France or Spain. In Spain, firms accounting for $41 \%$ of temporary employment quoted flexibility as the only reason (Bielenski and Kohler, 1992). In this respect, the fact that France and Spain place considerable restrictions on the use of temporary contracts and still have very high proportions of employees in this category, is a sign that limitations on adjustment of permanent staff play a key role in encouraging temporary employment.

To further this idea, we look at an index of European employers' perceptions of the severity of employment protection regulations in $1985 .^{5}$ Figure 1 plots this index against the ranking of the change in the proportion of temporary employment from 1985 to 1991 ( 1 stands for the least regulated and the lowest increase and 11 for the opposite) ${ }^{6}$ The visual impression of a positive relationship is confirmed by a rank correlation coefficient of 0.56 ( $t$-ratio: 2.6). Clearly, labour market rigidity is in fact related to the use of temporary contracts.

2.1.5 Part-time versus temporary employment. Can the same argument be made about part-time employment? From the point of view of labour rigidity, lumping together these forms of atypical employment is misleading for several reasons. First, although part-time employment is, like temporary employment, concentrated among women and especially youths, involuntary part-time employment is less common than involuntary temporary employment (with the former going from $4 \%$ in Spain to 35\% in Italy, see OECD, 1993). Secondly, in the 1989-90 survey quoted above, only $27 \%$ of employers said that they hired part-time labour to achieve direct cost advantages (although the proportion was notably higher in the

5 The source for this index is CEC (1993), which is itself based on the work of Emerson (1988) and Bertola (1990).

6 The rigidity index is absent for Spain and Portugal for 1985, but exists for 1989. So we rank these countries in 1985 between the same two countries adjacent to them on either side in 1989, ignoring for this purpose those countries which changed position (namely, the Netherlands in the case of Spain and Germany in the case of Portugal). 


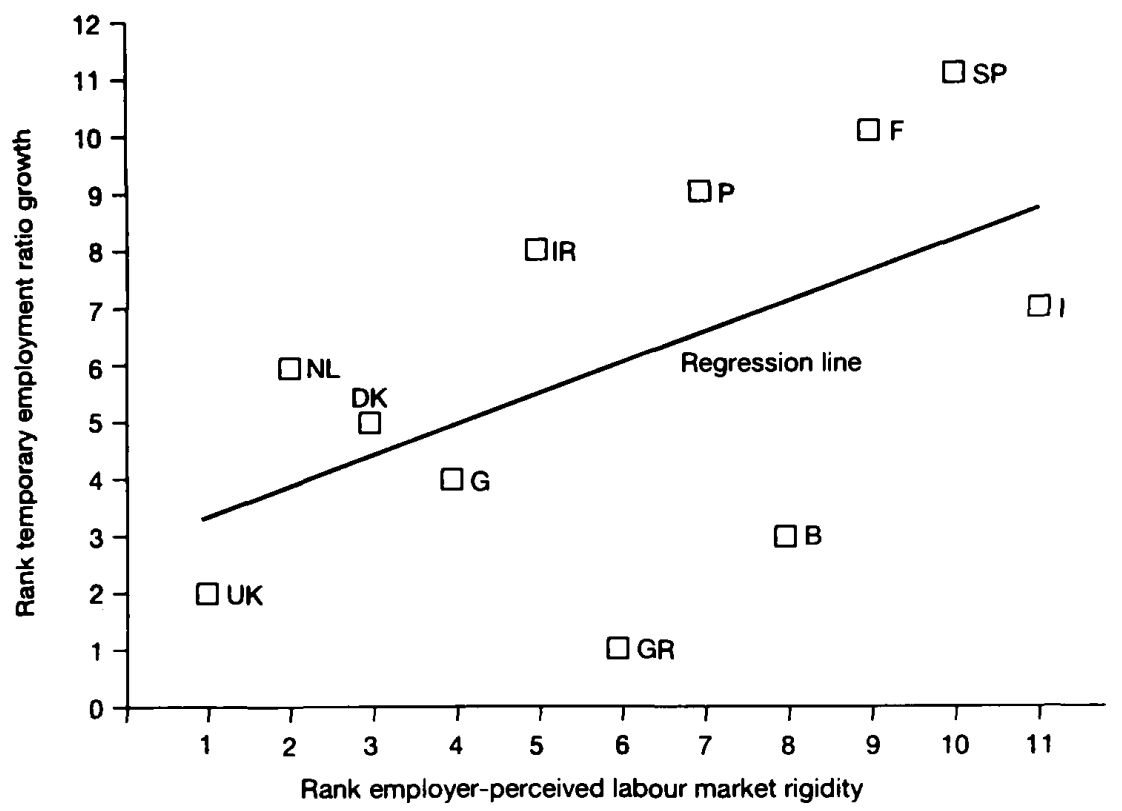

Figure 1. Labour market rigidity and growth in temporary employment

Source: As footnote 5.

UK). ${ }^{7}$ Thirdly, carrying out the same informal test as above, we find a negative and insignificant rank correlation between employer-perceived labour market rigidity in 1985 and the increase in part-time employment from 1985 to 1991 (coefficient: -0.21 , $t$-ratio: 1.2). All of these features suggest that part-time jobs mostly play the role of matching the needs of employers and employees, rather than the flexibility-enhancing role played by temporary employment. In Section 5 , we will see that part-time employment does not appear to generate the type of insider wage effects found for temporary employment.

2.1.6 Two other issues should be mentioned. First, little is known about the differences between the wages of permanent and temporary employees in European countries. Ideally one should control for worker and job characteristics in order to estimate a type-of-contract wage premium. As

7 These advantages would presumably be obtained through part-time workers receiving either lower wages or lower fringe benefits than full-time workers (for a summary, see the articles in Rodgers and Rodgers, 1989). 
far as we know, this has not been done on a cross-country basis. In the next sub-section we will report the results available for Spain. Second, by focusing on the proportion of temporary jobs in the stock of employees we are missing the share of temporary employees in labour flows. As recently emphasised by Burda and Wyplosz (1994), flows between employment, unemployment and non-participation are several times larger than the stock of unemployed. Since temporary contracts entail lower adjustment costs, workers on these contracts should also be overrepresented in job inflows and outflows. In fact, this appears to be the case in the EC. According to the EC Commission (1990), in 1989, $20 \%$ of men and $17 \%$ of women in unemployment were in this situation because of the expiration of a temporary job, while these jobs only accounted for $8 \%$ of total EC employment. Also, in the seven countries reported in Table 2, while only $4 \%$ of permanent employees in 1991 were unemployed or out of the labour force in $1990,31 \%$ of temporary employees were in those states. This suggests that temporary jobs have led to increased employment opportunities for the unemployed. Nevertheless, in countries like Spain, where these contracts have soared, this fact may just reflect that there is a continuous turnover among temporary workers, who go from temporary employment to unemployment and back again. This turnover increase may be beneficial in reducing long-term unemployment, but may also reinforce a dual labour market, with undesirable consequences on several fronts, and in particular on wage growth.

\subsection{The Spanish case}

2.2.1 Brief overview. At the death of Franco, in 1975, Spain had a scarcely developed system of industrial relations and a very rigid employment protection law. Wage bargaining has slowly evolved towards European patterns, while labour regulations have changed in a very peculiar way (see Box 1).

Permanent (indefinite) labour contracts entail high severance pay. To reduce labour market rigidity, the Spanish Socialist government introduced fixed-term contracts in late 1984 (more precisely, this is when important restrictions were lifted on a law passed in 1980). These contracts may be used for any activity (temporary or not), may be signed for short periods (previously six months, one year since April 1992) and renewed for up to three years (four years since 1993). When the period of the last possible renewal expires the firm must either keep the worker on a permanent basis or dismiss him/her. In the latter case, it must wait for a year before hiring another person on a fixed-term contract for the same position. Non-renewal of fixed-term contracts entails low firing costs and cannot be appealed to labour courts. Special fixed-term contracts for 


\section{Box 1. The Spanish wage bargaining and severance pay systems}

The current wage bargaining system is quite new, since unions were not legally recognised until 1977 . There are two main unions, which comprise around $70 \%$ of all representatives bargaining with employers. Union affiliation is low, around $10 \%$. But this is a poor measure of union power, because the terms of industry-wide agreements are binding floors for all firms in the sector, so that in 1984-91 almost $82 \%$ of all employees were covered by collective agreements. Those agreements corresponding to a single firm are concentrated in large firms and comprise about $20 \%$ of workers covered by collective bargains. Agreements last for a year, and they usually stipulate wages and hours of work, but hardly ever employment levels (Jimeno and Toharia, 1994, chapter 3).

As to severance pay, the law distinguishes between collective and individual dismissals. The former (roughly defined as firing more than $10 \%$ of a firm's employees within a month) have to be approved by the Labour Ministry, which often does so only if workers' representatives agree. As a result, firms normally pay more than the legal severance pay of $\mathbf{2 0}$ days per year of service. The latter is also the mandated pay for individual dismissals, but in this case firms are normally taken to the labour court, which usually rules the dismissal 'unfair' (firing for economic reasons is legally unfair), thus granting a severance pay of 45 days per year of service (plus legal costs). By comparison, some types of fixed-term contracts bear no firing costs at all, while other types imply 12 days of wages per year of service. The regulation of fixed-term contracts will undergo important changes during 1994.

youth training were introduced at the same time, with reductions in social security contributions. Temporary work agencies have been illegal in Spain until 1994 (though they operated de facto), so all recorded temporary employment is under fixed-term contracts.

The introduction of these contracts shortly preceded the 1986-90 boom - in which real GDP grew by $3.4 \%$ on average - and they have been used heavily. Over that period total employment increased by $3 \%$ per year, the number of employees by $4.8 \%$, and $80 \%$ of all contracts registered at employment offices were fixed-term ( $11 \%$ of the latter were for youth training). As a result, one-third of all employees currently hold a temporary job. Because these contracts are now so important, they have had effects on most key labour market variables, which we now briefly 
survey. (Caution is required before drawing conclusions given the brevity of the period during which fixed-term contracts have been extensively used.)

2.2.2 Employment has become more variable over the business cycle because the use of temporary contracts allows firms to reduce firing costs. Evidence provided by Bentolila and Saint-Paul (1992) shows that in large manufacturing firms labour demand became more responsive to output fluctuations during 1985-88 due to the introduction of fixed-term contracts. In order to provide a rough measure of aggregate developments, Figure 2 (using calculations by Garcia Perea and Gomez, 1993; the 1993 data are forecasts based on data up to November 1993) plots the average growth rates of output and employment over the period 1966-93. It reveals that in the last expansion (1986-90), the increase in employment - given output - was much higher than the last time around (1966-74). Employment has not fallen in the current recession more than in the last one (1975-85); this may be because Spain is still half-way through the recession.

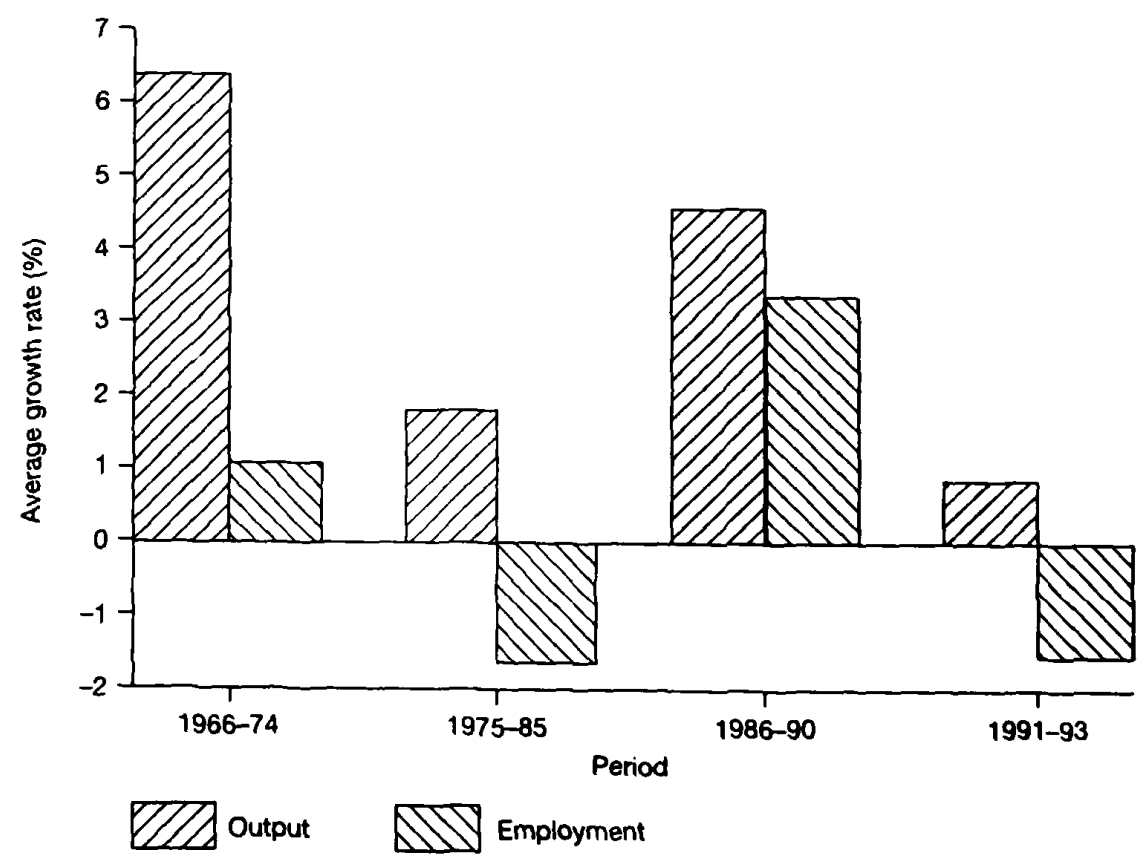

Figure 2. Output and employment growth in Spain

Source. See Section 2.2.2. 
2.2.3 Labour turnover has increased. This is backed by several pieces of evidence. Thus, 4.7 million contracts were signed in 1992, while in net terms 425,000 employees lost their jobs. The ratio of the inflow of registered job demands (at employment offices) to employment has increased from 3.4 in 1980-84 to 6.5 in 1991-92 (both being periods of recession). The average length of these contracts is short, 18 to 20 months (in 1986-87, see Segura et al., 1991). As mentioned before, a positive effect of a larger turnover is that it may help reduce long-term unemployment. Indeed, $6.2 \%$ of workers with a temporary contract in 1990 had been unemployed for more than two years in 1989, and longterm unemployment fell by 6 percentage points between 1985 and 1991.

The higher labour turnover, however, may have also had a negative impact on long-term productivity. While more employment volatility may have reduced the cyclicality of labour productivity (the ratio of output to employment), productivity growth has actually fallen. It is conceivable that the short tenure length inherent in fixed-term contracts discourages investment in human capital on the part of both firms and workers. Alternatively, fixed-term workers may exert less effort than permanent employees, given that they expect to be fired anyway. ${ }^{8}$ There is some evidence of a negative correlation between temporary employment and productivity growth in Spanish manufacturing. With sectoral data, Jimeno and Toharia (1992) find, for 1988, that once worker characteristics are controlled for, an increase in the proportion of fixed-term employment of one percentage point is associated with a fall of $9 / 10$ th of one percent of the sector's labour productivity growth. Total factor productivity growth, which is a better measure of efficiency (since it includes the increase in the capital stock), has also fallen in the past few years. In this case, however, a panel data study at the firm level, by Hernando and Vallés (1993), shows no influence of temporary employment during 1986-89. Both findings could be reconciled by a negative correlation between the capital-labour ratio and the proportion of temporary employment, a hypothesis which looks quite sensible. ${ }^{9}$

${ }^{8}$ Conversely, of course, fixed-term workers may exert more effort, due to the higher credibility of a threat by the firm to fire them if caught shirking, or because they want to raise their likelihood of being promoted to permanent employees (see Jimeno and Toharia, 1993b).

9 From the definition of total factor productivity (TFP) growth:

$\partial(\Delta T F P) / \partial(\Delta \phi)=\delta(\Delta L P) / \partial(\Delta \phi)-(1-\alpha) \partial(\Delta K-\Delta N) / \partial(\Delta \phi)$

where $\Delta$ is the growth rate, $L P$ is labour productivity, $K$ is capital, $N$ is employment, $\phi$ the proportion of fixed-term employment and $\alpha$ the participation of labour in value added. So, the lefthand side may be zero if the two terms in the right-hand are equally sized. 
A second consequence of higher labour turnover has been disequilibrium in public finances. Since unemployment insurance was provided after just 6 months of work, the revenues of the unemployment compensation system fell short of benefit payments as the economy slowed down. In response, the government raised (in April 1992) the minimum period of previous work to be eligible for unemployment insurance to 1 year and lowered the amount of benefits.

2.2.4 Effect on wage growth. That the introduction of temporary contracts could have pervasive wage effects was relatively unexpected, and is the main theme of the rest of this paper. We start by looking at the wage drift, i.e. the difference between the rate of growth of wage rates agreed in collective bargains and actual average earnings growth. In the 1980s wage drift used to be around 2 percentage points, but after 1987 it was abnormally low, even becoming negative. Since 1990 it has become positive again (see Figure 3). On the other hand, in the latter period bargained wage rates in real terms started to rise, even though Spain was in recession (see Figure 4). How could both observations be reconciled? Our interpretation is two-fold.

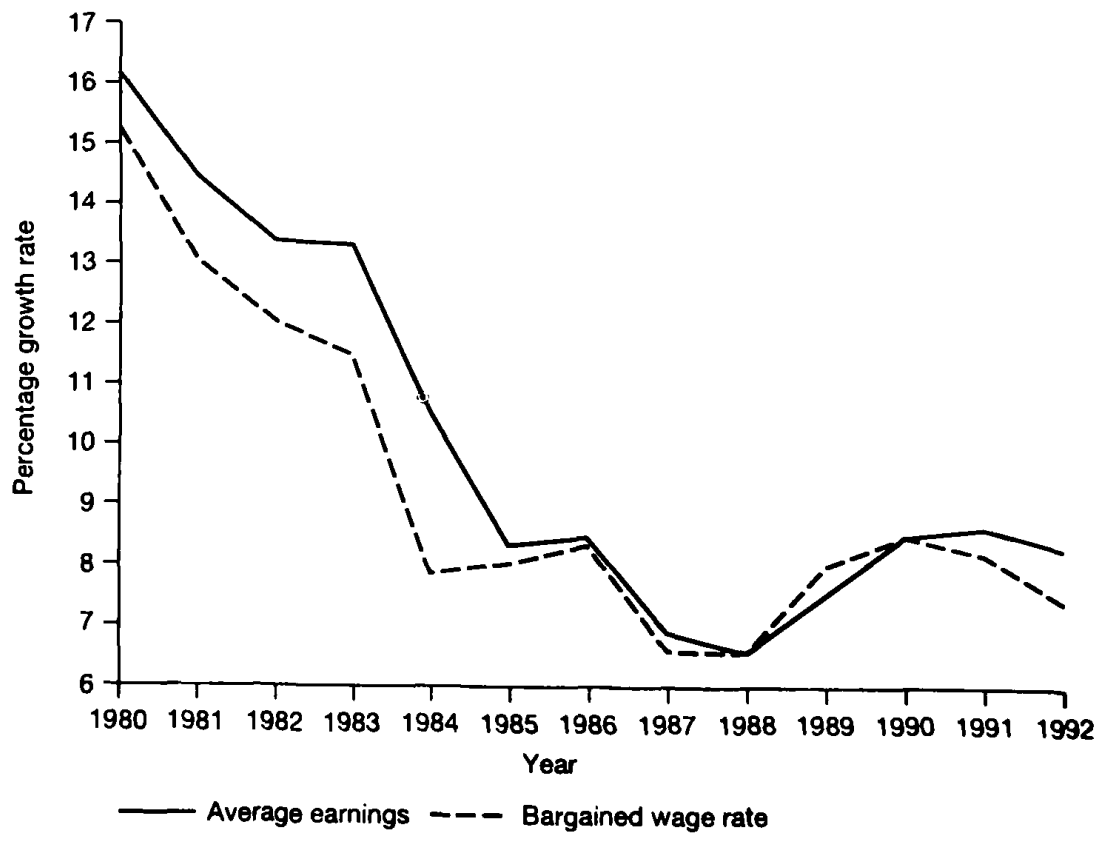

Figure 3. Bargained wage rates and average earnings in Spain

Source. See Section 2.2.2. 


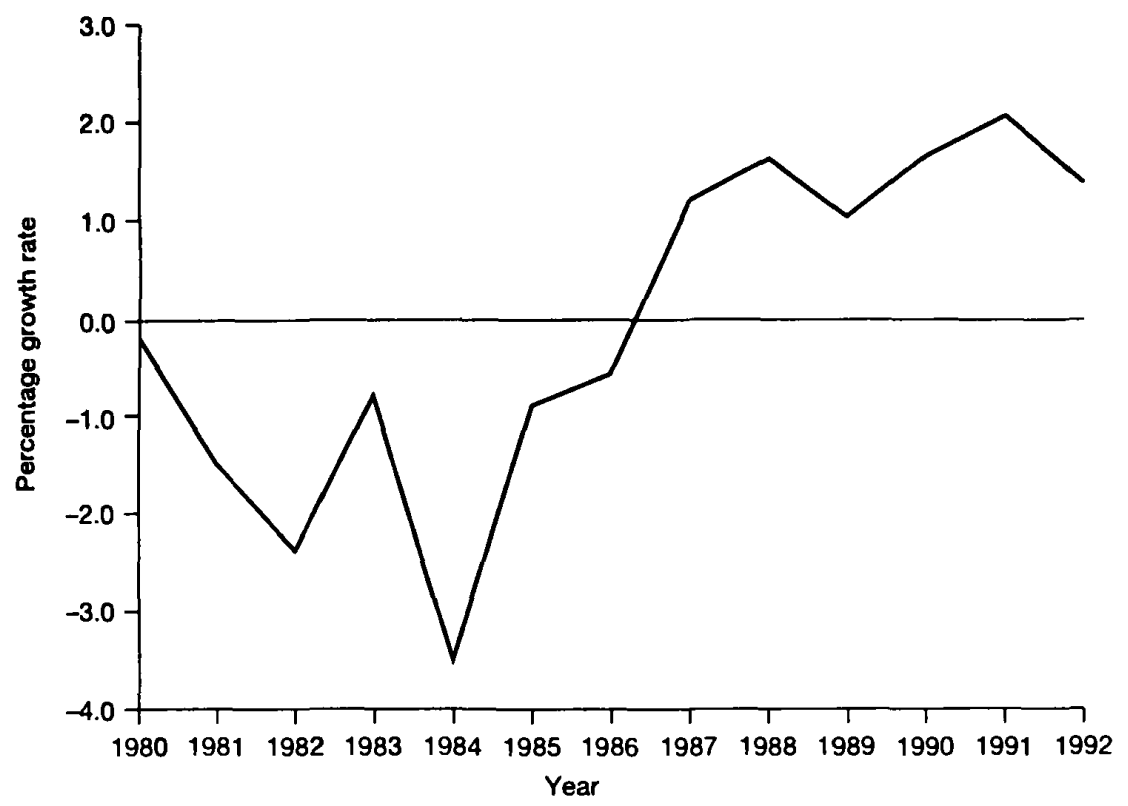

Figure 4. Real bargained wage rates in Spain (Average annual growth rate, \%)

Source See Section 2.2.2.

First, the evolution of the wage drift is consistent with workers on fixedterm contracts receiving lower wages. As a result, average wages have increased by less than usual when the proportion of such workers has increased rapidly, and the drift has shrunk. On the other hand, when the proportion of temporary employment has stabilized (around 1990), average wages have tended to rise, as a result of insiders' wage push, and so has the drift. There is evidence indicating that workers on fixed-term contracts receive lower wages than those on permanent contracts. (Discrimination based on contact type is illegal in Spain, but apparently employers are relatively free to choose the occupation in which they classify new workers, so that through under classification they can actually pay them less.) Jimeno and Toharia (1993a) estimate the wage premium to be between $8 \%$ and $11 \%$.

Second, in principle, temporary employees should be compensated for lower job security through higher, not lower, wages. The estimated negative premium for temporary employees may be due to unobservable characteristics (this is Alba's, 1991, view), but it is more likely that it reflects the importance of insider factors in wage bargaining. The right of temporary workers to be represented in works councils varies across 
countries. For example, it is absent in Germany and Portugal, partial in Belgium and France, and unrestricted in the rest of the EC. In Spain, regardless of contract type, any worker with one-month's seniority can vote in the elections to works councils and any worker with six-months' seniority can be elected. Yet, if these workers' interests are represented only partially or not at all in wage bargains, then insider wage setters (permanent employees) may ask for higher wages, exploiting the fact that temporary employees will bear the consequences. This is the theme of the rest of the paper.

\section{An insider-outsider interpretation of permanent and temporary employment}

\subsection{The Buffer Effect}

The starting point of the insider-outsider distinction (see Layard et al, 1991) is that wages are the outcome of a bargaining process whereby firms and their employees share the economic rent captured by the firms on goods markets. Here we identify the permanent workers as those holding permanent contracts. ${ }^{10}$ The main results are presented here, leaving the details to Appendix A.

We adopt the so-called right-to-manage description of wage-setting (Nickell and Andrews, 1983) which seems to fit the Spanish firm-level wage bargaining system well (see Box 1). First, wages result from a bargain between the firm and its workers, who take into account the expected effect of their decision on employment. Then, after the level of product demand is known, the firm sets employment, output and prices. When workers' representatives in wage bargains pursue only the interests of permanent workers, disregarding those of temporary workers and the unemployed (the outsiders), they will try to achieve the highest possible expected level of income of the median permanent workers - taking the wage of temporary employees as given - which is given by:

Expected income $=($ Survival probability $) \times($ Insiders' wage $)$

$$
+(1-\text { Survival probability }) \times \text { (Alternative income) }
$$

The survival probability is the probability that an insider will still be employed with the firm once wages are set and the level of demand is known. To compute it, we make two assumptions concerning dismissals:

\footnotetext{
${ }^{10}$ In Lindbeck and Snower (1988a) new workers or entrants gain insider status after one period with the firm. We ignore such dynamics, since the probability of a temporary employee becoming a permanent one is low in Spain, between 12\% (Alba, 1991) and 22\% (Segura a al, 1991).
} 
that temporary workers are the first ones to be fired (because of their lower firing costs), and that, if permanent workers are to be fired, layoffs are random. The alternative income is the expected income of a laid-off workers, itself a weighted average of the probability of finding another job times the expected wage in such job (the outside wage), plus the probability of being unemployed times the unemployment benefit.

The union realises that if demand is high, all insiders will be employed and the survival probability will then be $100 \%$, but if demand is low, some insiders will lose their jobs and the survival probability will be lower. The probability that any single permanent worker will keep his job is measured by the ratio of permanent employment to the union's target employment level. It is smaller the larger is that target (i.e. the number of insiders) relative to expected total employment and, therefore, the larger the wage.

This gives rise to the buffer effect. When the proportion of temporary employment in total employment, denoted by $\phi$ for short, rises the union's employment target becomes smaller relatively to expected total employment and insiders' representatives ask for higher wages.

\subsection{The bargaining effect}

When they bargain the firm and the union each attempt to maximize their rents over and above what they could get in the absence of an agreement (which would lead, e.g., to a strike). The workers' relative bargaining power is described by a parameter, $\beta$, which can be related to the firm's likelihood of avoiding bankruptcy or its financial health (e.g. profits, liquidity, etc.). ${ }^{11}$ Interestingly, another variable affecting $\beta$ is the proportion of temporary workers. This provides the second effect of $\phi$ on wages, the bargaining effect, which comprises two sub-effects working in opposite directions.

The harassment effect (Lindbeck and Snower, 1988a) increases $\phi$. Insiders strengthen their bargaining position by threatening to be uncooperative with temporary employees. If by becoming relatively less numerous insiders become more essential to the production process, the firm will prefer to accept their wage claims rather than keep permanent workers' positions vacant or replace them with new workers with lower productivity.

\footnotetext{
"Although in a Nash bargaining game-axiomatic approach, the relative bargaining power of the union, $\beta$, basically depends negatively on its discount rate (how 'willing to go without the cake' the union is, in the words of Layard ot al., 1991), it is difficult to model the effects of the previous variables through that rate. Thus, for practical purposes, we model them directly through $\beta$.
} 
The discipline effect tends to reduce $\phi$. Given their lower firing cost, temporary workers should be wary of engaging in strikes led by permanent employees. As the proportion of temporary workers rises strike activity declines, which erodes the power of permanent workers.

\subsection{Empirical formulation}

This description of wage bargaining as rent-sharing between firms and their insider workers can be represented by the markup of permanent workers' wages over outsiders' wages. This markup will be higher the greater is the firm's market power, which determines the size of the overall rent to be shared, the greater is the union power $(\beta)$, and the lower is the number of insiders in relation to expected employment. The result, formally developed in Appendix A, can be expressed in the following equation for the wages of permanent workers (this is a specification familiar in the insider-outsider literature, see Layard et al, 1991):

Insider wages $=c_{1}+\lambda($ Inside factors $)+(1-\lambda)$ (Outside factors $)$

$$
+c_{2} \text { (Firm's market power) }+c_{3} \text { (Workers' bargaining power) }
$$

The parameter $\lambda$ is the insider weight. Inside factors relate to the firm's expected ability to pay, through its nominal productivity (production or sales per employee), and the expected size of the union, through the change in the number of insiders. Notice that insider employment growth raises the bargained wage because, given current membership, the lower last period's employment (i.e. the higher is employment growth) the more protected from losing their jobs will the insiders be. ${ }^{12}$ Outside factors are those affecting workers' alternative income, i.e. the unemployment rate, wages in other firms, and unemployment benefits (the latter as a proportion of average wages, i.e. the so-called replacement ratio). The last two elements in the equation are the firm's market power and workers' relative bargaining power. Both variables increase the markup: the first by raising the firm's ability to generate rents and the second by raising the share of the pile that workers can extract from the firm.

\footnotetext{
12 This is normally called the membership hysteresis term, as opposed to outsider hysteresis arising from long-term unemployment. See Section 4.1.
} 


\subsection{The role of temporry employment}

Equating insiders with permanent workers departs from standard insideroutsider formulations in two main respects. First, what exerts pressure on bargained wages are changes in permanent, rather than in total, employment. Second, the proportion of temporary employment on wages, $\phi$, affects wages in three ways.

One is the buffer effect, according to which the proportion of temporary workers in total employment is one of the inside variables. The size of this effect on bargained wages is measured by the insider weight, $\lambda$. It is possible to generalise and postulate that temporary employees are also considered in the union's employment target, with a weight of $\tau$; hence, $\tau=1$ implies full equivalence between both types of workers and $\tau=0$ is the other extreme of full disregarding of temporary employees by the union. ${ }^{13}$

The second particularity is the bargaining effect. It corresponds to the impact of the proportion of temporary employment on workers' bargaining power. As mentioned before, its sign will depend upon the relative strength of the harassment effect (positive) and the discipline effect (negative). Hereafter, the net size of this effect will be denoted as $\delta$.

Finally, there is a composition effect, which comes from data availability issues. We do not have separate information on wages earned by permanent workers and those earned by temporary workers. We only have the average labour cost per employee. This could, in principle, constitute a problem. However, from a relationship.linking the permanent workers' wage to the average wage we know that replacing the former with the latter introduces a further effect of $\phi$, with a coefficient of $-1 .^{14}$

In summary, the coefficient of $\phi$ comprises three effects: the buffer effect, with a coefficient of $\lambda$; the bargaining effect, with a coefficient of $\delta$; and the composition effect, with a coefficient of -1 . The sum $\delta+\lambda$ captures the effect of $\phi$ on permanent employees' wages, while $\delta+\lambda-1$ represents the overall effect of $\phi$ on average wages. Note that, if the coefficient on $\phi$ is not significantly different from the outsider weight, $1-\lambda$, then the bargaining effect will be absent.

\footnotetext{
${ }^{13}$ In Appendix $\mathbf{A}$ it is shown that a nonzero $\tau$ implies that the lagged proportion of temporary employment, $\left(\phi_{t-1}\right)$, should enter as a significant determinant of wages, with a negative sign. From this variable's coefficient we could estimate the weight of temporary employees in the union's employment target, and an estimate for $\tau$ lower than unity would imply the presence of the buffer sfect.

14 It can be shown that, with a Cobb-Douglas technology, the optimal demand for each type of labour implies the following approximate long-run relation between average wages $(w)$ and permanent employees' wages $\left(w_{p}\right)$ (in logs): $w=w_{p}-\phi+$ constant.
} 


\section{Testing the theory with data on Spanish firms}

\subsection{Main empirical results}

Our data come from the accounts of 1,167 manufacturing, non-energy, private firms over the period 1983-88. The sample represents around $13.5 \%$ of manufacturing employment in Spain, and corresponds essentially to large firms, a feature which fits well with the fact that firm-specific collective agreements are largely restricted to this type of firms. (Other features of the firms in the sample are shown in Table Bl of Appendix B.) By the same token, the results with this sample should not be mechanically extrapolated to the behaviour of small firms, which are the vast majority in Spain, or for firms in sectors, like construction or services, where the proportion of temporary employment is larger (so that the non-representation of temporary employees is less likely).

We allow for the lagged dependent variable to enter in the right-hand side, for various potentially relevant reasons: the existence of multi-period wage agreements, the concern of the bargaining unit with both wage levels and changes, and, lastly, the long-run nature of the optimal relative intensity in the use of both types of labour. The estimation is performed with panel data techniques for dynamic models, dealing with the potential correlation of firm-specific variables and the lagged dependent variable with the disturbance term by instrumenting with lagged values of the variables. ${ }^{15}$ After allowing for lags, the estimation period is 1985-88, making for a total of 4,668 observations. The preferred specification is presented in column 1 of Table 6. (Following similar studies - e.g. Wadhwani, 1987; Nickell and Wadhwani, 1990, 1991; or Blanchflower et al., 1990 - a number of variables have been introduced to proxy the effects on workers' relative bargaining power of profit - profits per employee - and of liquidity - the interest rate and the proportion of medium- and long-term debt).

The results are quite favourable to our hypotheses. ${ }^{16}$ First, while small, the insider weight $(\lambda)$ is estimated with precision. Its long-run (long-run parameters are calculated by dividing the short-run coefficient by one minus the coefficient on the lagged endogenous variable) value is about 0.11 , in line with estimates by Nickell and Wadhwani (1990) for the UK (0.11) and in between those pertaining to countries where bargaining is rather decentralized (Brunello and Wadhwani, 1989, report a value of

\footnotetext{
${ }^{15}$ The data are first-differenced to eliminate the effects of differences in skill levels, production technologies, etc., that remain invariant over time. For further details see Appendix B.

16 The long-run homogeneity in the inside and outside factors (i.e. $\lambda+(1-\lambda)=1$ ) was tested, not rejected and imposed. Statistical tests for this and other hypotheses appear in Table B2 of Appendix B.
} 


\begin{tabular}{|c|c|c|c|c|c|}
\hline & $\begin{array}{c}(1) \\
\text { Preferred } \\
\text { specification }\end{array}$ & $\begin{array}{c}(2) \\
\text { Time } \\
\text { dummies }\end{array}$ & $\begin{array}{c}\text { (3) } \\
\text { Sectoral } \\
\text { dummies }\end{array}$ & $\begin{array}{l}(4) \\
\text { Reduced } \\
\text { IV set }\end{array}$ & $\begin{array}{c}(5) \\
\text { Alternative } \\
\text { insiders }\end{array}$ \\
\hline $\begin{array}{l}\text { Wages } \\
\text { lagged* } \\
\left(w_{i,}\right)\end{array}$ & $\begin{array}{l}0.267 \\
(8.14)\end{array}$ & $\begin{array}{l}0.245 \\
(5.81)\end{array}$ & $\begin{array}{c}0.244 \\
(8.52)\end{array}$ & $\begin{array}{c}0.250 \\
(8.16)\end{array}$ & $\begin{array}{l}0.273 \\
(7.31)\end{array}$ \\
\hline $\begin{array}{l}\text { Nominal } \\
\text { productivity* }\end{array}$ & $\begin{array}{l}0.078 \\
(2.76)\end{array}$ & $\begin{array}{l}0.077 \\
(2.42)\end{array}$ & $\begin{array}{c}0.072 \\
(2.80)\end{array}$ & $\begin{array}{l}0.079 \\
(2.93)\end{array}$ & $\begin{array}{l}0.090 \\
(2.93)\end{array}$ \\
\hline $\begin{array}{l}(p+y-n)_{i t} \\
\text { Growth perm. } \\
\text { employ.* } \\
\left(\Delta n_{\text {pis }}\right)\end{array}$ & $\begin{array}{l}0.030 \\
(2.90)\end{array}$ & $\begin{array}{l}0.028 \\
(2.98)\end{array}$ & $\begin{array}{c}0.022 \\
(3.17)\end{array}$ & $\begin{array}{l}0.029 \\
(3.15)\end{array}$ & $\begin{array}{c}-0.021 \\
(2.76)\end{array}$ \\
\hline $\begin{array}{l}\left(\Delta u_{\text {pis }}\right) \\
\text { Outside } \\
\text { wage } \\
\left(w_{t}\right)\end{array}$ & $\begin{array}{c}0.655 \\
(-)\end{array}$ & $\overline{(-)}$ & $\begin{array}{c}0.684 \\
(-)\end{array}$ & $\begin{array}{c}0.671 \\
(-)\end{array}$ & $\begin{array}{c}0.637 \\
(-)\end{array}$ \\
\hline $\begin{array}{l}\text { Unemployment } \\
\text { rate } \\
\left(u_{s}\right)\end{array}$ & $\begin{array}{c}-0.928 \\
(5.60)\end{array}$ & $\overline{(-)}$ & $\begin{array}{c}-0.836 \\
(4.53)\end{array}$ & $\begin{array}{c}-0.985 \\
(6.92)\end{array}$ & $\begin{array}{c}-0.978 \\
(6.07)\end{array}$ \\
\hline $\begin{array}{l}\text { Replacement } \\
\text { ratio } \\
\left(b_{t}\right)\end{array}$ & $\begin{array}{l}0.108 \\
(3.82)\end{array}$ & $(-)$ & $\begin{array}{l}0.106 \\
(3.50)\end{array}$ & $\begin{array}{l}0.112 \\
(4.07)\end{array}$ & $\begin{array}{l}0.119 \\
(4.37)\end{array}$ \\
\hline $\begin{array}{l}\text { Market } \\
\text { power } \\
\left(k_{j-1}\right)\end{array}$ & $\begin{array}{l}0.011 \\
(1.47)\end{array}$ & $\begin{array}{c}0.015 \\
(1.60)\end{array}$ & $\begin{array}{l}0.020 \\
(2.67)\end{array}$ & $\begin{array}{l}0.032 \\
(2.92)\end{array}$ & $\begin{array}{l}0.017 \\
(1.19)\end{array}$ \\
\hline $\begin{array}{l}\text { Profits per } \\
\text { employee } \\
\left(b n_{\text {id-1 }}\right)\end{array}$ & $\begin{array}{r}0.093 \\
(3.25)\end{array}$ & $\begin{array}{l}0.110 \\
(3.62)\end{array}$ & $\begin{array}{l}0.116 \\
(3.68)\end{array}$ & $\begin{array}{l}0.088 \\
(3.25)\end{array}$ & $\begin{array}{l}0.092 \\
(3.20)\end{array}$ \\
\hline $\begin{array}{l}\text { Interest } \\
\text { rate } \\
\left(r_{i t-1}\right)\end{array}$ & $\begin{array}{c}-0.016 \\
(1.51)\end{array}$ & $\begin{array}{c}-0.021 \\
(1.40)\end{array}$ & $\begin{array}{c}-0.012 \\
(1.19)\end{array}$ & $\begin{array}{c}-0.018 \\
(1.22)\end{array}$ & $\begin{array}{c}-0.006 \\
(0.78)\end{array}$ \\
\hline $\begin{array}{l}\text { Medium and } \\
\text { long-term debt } \\
\left(\text { mld }_{i t-1}\right)\end{array}$ & $\begin{array}{c}-0.034 \\
(2.58)\end{array}$ & $\begin{array}{c}-0.033 \\
(2.56)\end{array}$ & $\begin{array}{c}-0.034 \\
(2.60)\end{array}$ & $\begin{array}{c}-0.028 \\
(2.31)\end{array}$ & $\begin{array}{c}-0.018 \\
(1.49)\end{array}$ \\
\hline $\begin{array}{l}\text { Prop. of } \\
\text { temp. employt.* } \\
\left(\phi_{i k}\right)\end{array}$ & $\begin{array}{c}-0.477 \\
(8.68)\end{array}$ & $\begin{array}{c}-0.511 \\
(8.29)\end{array}$ & $\begin{array}{c}-0.510 \\
(8.40)\end{array}$ & $\begin{array}{l}-0.505 \\
(8.43)\end{array}$ & $\begin{array}{c}-0.302 \\
(2.76)\end{array}$ \\
\hline$m_{2}$ & 1.050 & 0.586 & 0.166 & 0.812 & 0.896 \\
\hline$S_{\mathrm{IV}}$ & $\begin{array}{c}39.13 \\
(42)\end{array}$ & $\begin{array}{c}37.17 \\
(41)\end{array}$ & $\begin{array}{c}40.36 \\
(41)\end{array}$ & $\begin{array}{c}27.43 \\
(25)\end{array}$ & $\begin{array}{c}39.66 \\
(42)\end{array}$ \\
\hline
\end{tabular}

Notes: Number of observations: 4,668. Period: 1985-88. Subscript $i$ denotes firms, $j$ refers to industry to which the firm belongs and $t$ denotes time. Coefficients in the first two columns are two-step robust estimates. Heteroskedasticity-consistent $t$-ratios in parentheses. A superscript $\left(^{*}\right)$ denotes instrumented variables. The two IV (instrumental variables) sets are described in Appendix B. A constant term was initially estimated but was never significant. $m_{2}$ : test for second-order serial correlation. $S_{\mathrm{IV}}$ : Sargan test of overidentifying restrictions (degrees of freedom). 
0.33 for Japan) or very centralized (Holmlund and Zetterberg, 1989, estimate a value of 0.04 for Sweden). Also, our estimate is almost identical to that obtained by Andrés and García (1993), for 89 Spanish manufacturing sectors over 1978-86. The low value of $\lambda$ is not evidence against the insider-outsider model: firm-level variables have a much greater variance than aggregate variables, so that inside factors may explain a large proportion of the variation in wages.

Second, the long-run effect of the proportion of temporary workers $(\phi)$ on average labour costs is equal to -0.64 : a one-percentage point increase in $\phi$ lowers average labour cost by about two-thirds of one percent. This value is not too far, in absolute value, from the outsider weight, 0.89 . Equality in absolute value of both coefficients is however statistically rejected, which implies that there is a direct effect of the temporary employment ratio on the relative power of insiders. The difference $(\delta=0.89-0.64)$, implies that an increase of one percentage point in the temporary employment ratio raises the growth rate of permanent workers' wages by about one-third of one percent.

Third, the hypothesis that permanent workers do not care about temporary employees when setting their employment targets $(\tau=0)$ is not statistically rejected. Thus the buffer effect is present to its full extent.

Fourth, the membership hysteresis effect, captured by the change in the number of insiders is well determined and shows, in agreement with the theory, a small positive coefficient. This is remarkable, since this type of hysteresis effects is hardly robust in the literature (see, e.g., Nickell and Kong, 1992). Furthermore, the implied share of both labour types is 0.62 , a rather sensible value.

Fifth, the effects of outside variables, like the average wage or the unemployment rate, are strong and have the expected signs. We have however been prevented, by the shortage of cross-sections, from introducing other aggregate variables. In particular, we wanted to include the proportion of long-term unemployment to capture so-called outsider hysteresis effects. According to that view, the long-term unemployed are significantly less competitive than the short-term unemployed because they progressively lose both their motivation and their skills (Nickell, 1987). To circumvent the difficulty, we formed a composite variable with the unemployment rate $(u)$ and the replacement ratio $(b)$, using the coefficients estimated in the first column of Table 6 . Including then the proportion of long-term unemployed (those unemployed for more than a year) we found a positive coefficient $(0.36)$ as expected, but not significant. This is not too surprising, since in Spain the long-term unemployed do not appear to have had much more difficulty in finding jobs than the short-term unemployed and, in particular, the proportion of long-term unemployment fell right from the start of the last expansion. 
To the extent that the availability of temporary jobs may have raised the re-employment probabilities for the long-term unemployed, this is a beneficial effect captured by our results. ${ }^{17}$

Lastly, though they are not of direct interest to this study, we may note that both the market power measures and the firm-specific liquidity effects are significant, though individually some of them show weak effects.

\subsection{Checking robustness}

For skeptical (and technically-oriented) readers, we briefly discuss in this section the robustness of the previous results to changes in the adopted assumptions. (Further empirical specification checks are reported in Appendix B.)

The first important issue to address is how the results change when the simplifying Cobb-Douglas assumption is dropped in favour of a more general constant elasticity of substitution (CES) production function. In Appendix A we show that, if the elasticity of substitution is larger than unity, the previously estimated effect of the temporary employment ratio on the wages of permanent employees (0.35) represents an upper bound. Nevertheless, the bias is small. So, for $\phi=0.22$ (the 1985-91 national average), an elasticity of substitution of 4 and a relative efficiency of temporary workers of $0.85,{ }^{18}$ the effect of a one percentage point increase in $\phi$ on insiders' wages would be 0.34 instead of 0.35 . The effect of the larger elasticity of substitution is, however, nonlinear, and for a rise of 10 percentage points in $\phi$, the effect would be 2.52 instead of 3.50 . (These effects are not sensitive to the starting value of $\phi$ : for example, if we start from $\phi=0.10$, the average ratio of large manufacturing firms in the last sample year instead of the national value of 0.22 , we get virtually identical results.) The elasticity of substitution would have to be huge in order to make the joint buffer-bargaining effect negligible.

In column 2 of Table 6 , we replace aggregate variables by time dummies which capture aggregate common variation in the data, obtaining similar results. In column 3 , we introduce 13 sectoral

\footnotetext{
${ }^{17}$ We could also include in the equation the economy-wide temporary employment ratio. Its increase reduces the likelihood that an insider who is dismissed and hired by another firm will get a permanent job, which tends to restrain his wage demands. We recognize the potential validity of this point, made by Chris Pissarides, but have not attempted to incorporate it due to the shortage of crose-sections.

18 The value of the elasticity of substitution $(\sigma)$ arises from the fact that, from Table 1 , the ratio of temporary to permanent workers has risen by 3.7 times between 1985 and 1991, whereas a good guess of the fall in the relative cost of temporary workers is around $40 \%$. Then $\sigma=\log (3.7) / \log (1.4) \simeq 4$.
} 
dummies, which turn out to be insignificant. Moreover, we also found that the set of sectoral dummies intersected with time dummies - which may capture variations in the skill composition of permanent and temporary workers across time and sectors - were not significant. This suggests that our assumption that skill composition and the like are stable over the sample period is not rejected (see more in Appendix B). In column 4, where we use a reduced instrument set, the results are again very similar, which allows us to feel somewhat protected against recent criticisms of potential identification problems in wage setting equations (Manning, 1992). (The lack of identification would arise from our equation containing all the variables that appear in the labour demand equation, although they do so only as expectations.)

In column 5 we check one of our key results, namely that insiders' hysteresis arises from the change in permanent employment rather than in total employment. When the latter $(\Delta n)$ instead of the former $\left(\Delta n_{p}\right)$ is used, its coefficient is negative and significant, in opposition to the theoretical prior in a model where all employees are insiders with permanent employees.

Lastly, in order to analyse the degree of sectoral heterogeneity in the parameters, we have included the interaction of the relevant insider variables with sectoral dummies, finding that only the coefficients $\lambda$ and $\delta$ show some degree of variation across industries. Estimates of the buffer effect, $\lambda$, vary from $0.7 \%$ to $24 \%$, tending to be inversely related to productivity gains in each sector. (The estimates are reported in Dolado and Bentolila, 1993. See Appendix B for further interpretations.) As regards the bargaining coefficient, $\delta$, we found it to be positively correlated with an industrial strife index, measured by the average number of working days lost per employee by industry in 1986-89. This index should not have a clear correlation with the harassment effect but it should be negatively correlated with the discipline effect. Thus, under our hypothesis on the determinents of the bargaining effect, the ranking of $\delta$ should be highly correlated with the strike index, and it is (the rank correlation is 0.8 ).

\section{Four EC countries}

In this section we provide further evidence for four European countries: Denmark, France, West Germany and the UK. Although the number of countries is small (due to data availability), the experiences of these four countries cover a wide range of experiments: Denmark and the UK have permissive regulations, Germany has moderate ones, and France has the tightest of the four. 


\begin{tabular}{|c|c|c|c|c|}
\hline & Denmark & France & W. Germany & UK \\
\hline $\begin{array}{l}\text { Wages } \\
\text { lagged }\end{array}$ & $\begin{array}{r}0.179 \\
(3.68)\end{array}$ & $\begin{array}{c}0.533 \\
(11.06)\end{array}$ & $\begin{array}{r}0.438 \\
(5.73)\end{array}$ & $\begin{array}{l}0.383 \\
(9.63)\end{array}$ \\
\hline $\begin{array}{l}\left(w_{i t-1}\right) \\
\text { Nominal } \\
\text { productivity* }\end{array}$ & $\begin{array}{l}0.134 \\
(2.36)\end{array}$ & $\begin{array}{l}0.100 \\
(1.89)\end{array}$ & $\begin{array}{c}0.091 \\
(1.61)\end{array}$ & $\begin{array}{l}0.095 \\
(3.92)\end{array}$ \\
\hline $\begin{array}{l}(p+y-n)_{i t} \\
\text { Growth perm. } \\
\text { employ.* } \\
\left(\Delta n_{\text {pit }}\right)\end{array}$ & $\begin{array}{l}0.026 \\
(1.58)\end{array}$ & $\begin{array}{r}0.089 \\
(2.84)\end{array}$ & $\begin{array}{c}0.122 \\
(2.32)\end{array}$ & $\begin{array}{c}-0.058 \\
(2.70)\end{array}$ \\
\hline $\begin{array}{l}\text { Prop. of } \\
\text { temp. employt* } \\
\left(\phi_{i t}\right)\end{array}$ & $\begin{array}{c}-0.741 \\
(2.53)\end{array}$ & $\begin{array}{c}-0.367 \\
(2.31)\end{array}$ & $\begin{array}{c}-0.432 \\
(2.82)\end{array}$ & $\begin{array}{c}-0.373 \\
(1.62)\end{array}$ \\
\hline $\operatorname{AR}(1)$ & 1.35 & 2.06 & 2.82 & 3.17 \\
\hline$S_{\mathrm{IV}}$ & $\begin{array}{c}10.32 \\
(7)\end{array}$ & $\begin{array}{c}10.40 \\
(7)\end{array}$ & $\begin{array}{l}12.24 \\
(7)\end{array}$ & $\begin{array}{c}11.02 \\
(7)\end{array}$ \\
\hline$\lambda$ & 0.16 & 0.21 & 0.16 & 0.15 \\
\hline$\delta+\lambda$ & 0.10 & 0.21 & 0.23 & 0.39 \\
\hline
\end{tabular}

Notes: Number of observations: 104. Period 1984-91. Heteroskedasticity-consistent $t$-ratios in parentheses. A superscript $\left({ }^{*}\right)$ denotes instrumented variables. AR(1): GallantJorgenson test for first-order serial correlation, distributed as $\chi^{2}(1) . S_{\mathrm{IV}}$ : Sargan test of overidentifying restrictions (degrees of freedom).

Unfortunately, detailed panel data analysis was impossible for lack of comparable data sets at the firm level. However, we have been able to work at the sectoral level, using manufacturing data for 13 industries during the period 1984-91 (See Appendix B for sources and definitions). We report the results for the regressions in which economy-wide variables (i.e. with no cross-section variation) have been replaced by time dummies, since data for some of the aggregate variables were not available (e.g. the replacement ratio) and given that the results did not change significantly when variables such as the outside wage and the unemployment rate were instead included in the equation. ${ }^{19}$

From the regression results shown in Table 7 the following points are worth noting. First, there is evidence of an industry-specific hysteresis effect: the change in permanent employment $\left(\Delta n_{p}\right)$ appears with a fairly well determined positive coefficient, except in the UK, where it is negative, and Denmark, where it is not significant. Interestingly, these are

\footnotetext{
${ }^{19}$ The estimation method is instrumental variables in a pooled regression with fixedeffects, instrumenting the same variables as in Table 6, except the lagged dependent variable.
} 
the two countries which place minimum regulations on temporary contracts and there the representation of temporary workers in works councils is not restricted. To the extent that there is not much of a difference, in terms of adjustment costs, between permanent and temporary jobs, it is natural to expect a worse performance of the hypothesis that permanent workers are the insiders.

Second, estimates of the long-run insider weight $\lambda$, which go from 0.15 (United Kingdom) to 0.21 (France), are in line with those estimated elsewhere (see Holmlund and Zettert.rg, 1989; and Nickell and Kong, 1992). Third, the proportion of temporary employment $\phi$ is significant and negative, suggesting, as in the Spanish case, that in its effect on average wages the composition effect dominates via lower wages for temporary workers. At the same time, the effect of $\phi$ on permanent employees' wages seems to be positive. The estimated magnitudes (in the last line of Table 7) are between one-third and two-thirds of what is found in Spain (0.35), except in the UK, where the negative sign of the coefficient on $\Delta n_{p}$ clouds the interpretation of this coefficient. Moreover, given that the estimate of $\delta+\lambda$ is of about the same size as $\lambda$ in Denmark and France, it appears that the bargaining effect is small in both countries, i.e. the discipline and the harassment effects cancel each other. Indeed, $\delta$ is not significant in either case. One possible interpretation of a slightly larger effect in Germany than in France is that the representation of temporary workers in works councils is forbidden in Germany. However, when we test for the size of the buffer effect, the hypothesis that temporary workers are not represented in the bargaining process cannot be rejected in any country.

In order to see how these results compare with alternative specifications, we performed a number of experiments now briefly described. First, suppressing the proportion of temporary employment $(\phi)$ and replacing the change in permanent employment $\left(\Delta n_{p}\right)$ by the change in total employment $(\Delta n)$ resulted in uniformly worse fits, as measured by the standard error of the residuals, than those reported in Table 7 (with insider hysteresis effects becoming insignificant or wrongly signed). Second, since part-time employment in these four countries seems to be more important than in Spain, we tested the extent to which full-time workers could be playing the role of insiders in wage bargaining. So we redefined $\Delta n$ and $\phi$ as the change in full-time employment and the proportion of part-time workers, respectively. The results were again worse in terms of both the goodness of fit and the sign and statistical significance of the hysteresis term. However, we found that in two countries, Denmark and France, the null hypothesis that part-time workers are not represented in wage bargaining could not be rejected. Finally, we run the same regressions for eight service sectors for which 
atypical employment proportions were available, finding a lack of robustness in the results for all countries.

Bearing in mind the limitations of the econometric evidence, some regularities are worth mentioning: (i) It is temporary jobs, and not parttime jobs, that seem to generate insider hysteresis effects. A possible explanation is that the latter type of jobs tend to be poorer substitutes for full-time jobs and hence the insider forces are weaker; ${ }^{20}$ (ii) insider effects tend to be higher in those countries where permanent jobs bear high adjustment costs (France and Germany) reinforcing the power of insiders; (iii) the buffer effect is present and the bargaining effect is weak except in France and Germany; (iv) the latter two effects seem to appear in manufacturing rather than in services, presumably because, being in large number in services, workers with temporary contracts tend to be represented in the wage bargain.

\section{Lessons from Spain}

Over the 1980s indefinite-duration jobs have been losing ground to temporary jobs, particularly in France and Spain. This seems to be one of the most important ways in which firms have strived for increasing employment flexibility. In a way, this has not been a spontaneous phenomenon. Firms have responded to the incentives provided by several European governments trying to increase labour flexibility. What has been achieved, however, is flexibility at the margin, i.e. flexibility that especially affects certain groups of workers, but not the core of permanent employees, particularly in those countries where there are important obstacles to adjusting the permanent workforce. This has tended to create a dual labour market, not in the usual sense of having primary and secondary sectors in the economy, but in having a duality within firms. Increasing flexibility in this way may not be a complete blessing.

The potentially negative effects of atypical employment forms lie with wage setting. It is now widely believed that wage setting in some European countries is dominated by employed insiders who pursue their own interests in wage bargains, disregarding the employment prospects of unemployed outsiders. The danger is that, because their attachment to their firm is more fragile, workers in temporary jobs may not

\footnotetext{
${ }^{20}$ Rice (1990) provides estimates for the degree of substitutability of full-time and part-time employees in UK manufacturing.
} 
be considered on par with permanent employees. Thus, temporary employment may increase, not decrease, the share of the pie captured by permanent employees. This possibility is confirmed in the case of Spain, the country that has experienced he largest increase in temporary work in Europe. Results from four other EC countries are less clear-cut, but broadly confirm the message from Spain. In addition, they show that it is temporary jobs, rather than part-time jobs, that generate insider effects, and that those effects are stronger the less permissive is the legislation on adjustment of permanent employment.

The policy implications of our results are straightforward. If it is believed that labour market flexibility is beneficial for employment, an issue we have not addressed in this paper, then achieving it only at the fringes may have negative effects through larger wage growth. The risk is that such an effect is not immediately observed. At the beginning, when temporary employment increases, the lower wages and firing costs associated with temporary workers will reduce average labour costs (this is just a composition effect), as was indeed observed in Spain. For this reason, unit labour costs tend to fall, helping employment creation (even if temporary workers are less efficient). But once the proportion of temporary workers stabilizes, the buffer and bargaining effects will work at full strength, and unit labour costs will rise. If aggregate demand falls, higher unit labour costs imply that the brunt of the adjustment will be borne mainly by temporary workers, so that the composition effects works in reverse. All of that has, and is, happening in Spain: that the unemployment rate has quickly risen by 6 percentage points (from $16 \%$ to $23 \%$ ) between 1991 and 1993 is no doubt a reflection of the working of this perverse effect.

It is more advisable to directly reduce the rigidity affecting core workers, e.g. reductions in notice periods, severance pay, administrative delays of dismissals, and so on. The Spanish case provides a good example of an initial second-best situation with distorting institutions (high firing costs for permanent employees) which was not reformed, but was instead amended by the introduction of a new institution which increased flexibility only at the margin, and therefore did not necessarily lead to increased welfare.

Several caveats are worth mentioning. First, the fact that the results are less tight for European manufacturing sectors than for Spanish firms is a reminder that we should be careful in extrapolating results based on the behaviour of large Spanish manufacturing firms. Second, we need to explain why, recently, Spanish labour unions have strongly opposed temporary employment. This does not fit well with our view that the unions would be the main beneficiaries of the current arrangement, but can be explained as follows. 
The introduction of fixed-term contracts in Spain took place in late 1984, at the trough of a very long recession and at a time when the support of labour unions was essential to settle democracy. Both reasons help explain why one of the two main unions (Unión General de Trabajadores) tacitly agreed to the creation of this type of contracts. Spanish labour unions did not voice their strong opposition to these contracts until the boom was well under way and they saw the proportion of temporary workers going up significantly.

These facts suggest the following political economy or Trojan horse interpretation. Increasing the flexibility of permanent employees is usually politically difficult. This is probably why flexibility is implemented at the margin to start with and why unions insist on the establishment of conversion clauses (by which workers on fixed-term contracts have to be either fired or made permanent employees after a certain period). But, as Saint-Paul (1993) has recently pointed out, creating a two-tier labour market may facilitate the introduction of flexibility measures affecting core workers, as a coalition of temporary workers and the unemployed (i.e. the outsiders) grows in size over time. This story sounds particularly plausible in the Spanish case, where the potential coalition of proflexibility workers has almost reached half of the labour force $(19 \%$ in temporary contracts and $23 \%$ unemployed). This explains why unions now fear the introduction of legislation reducing firing costs for permanent employees, as currently discussed in Parliament.

This political economy viewpoint then suggests a third caveat. The negative wage effects of transitory two-tier systems may be a short-run phenomenon. Eventually long-run positive effects may arise if the new political balance leads to a permanent lowering of the firing costs of indefinite-contract employees. A last caveat is that two-tier systems have many further effects: increased labour turnover, lower productivity growth, lower duration of unemployment, and a worse financial situation of the unemployment insurance system (see OECD, 1993, for some evidence and speculation). We have partially illustrated their costs and benefits, as reflected by the Spanish experience. A final verdict on the desirability of two-tier systems should, however, consider all of these aspects together, some of which will only be resolved in the longer term.

\section{Discussion}

Wolfgang Franz

University of Konstanz and CEPR

Samuel Bentolila and Juan Dolado have written a very professional and stimulating paper. I very much enjoyed reading it and I learned a lot. 
If I like this paper, the problem is however that I do not always know why. To start with, I am unconvinced by Eurosclerosis as a motivation for the analysis. The comparison between the US and European experience in job creation in the eighties can be misleading: to start with, the contrast between the US and say Germany is not specific to the eighties. Employment in the non-farm, private sector remained fairly constant in West Germany over the last thirty years, at a time when jobs were continually being created in the US (see Franz and Gordon, 1993, Table 1). In addition, it is worth noticing that from 1990 to 1992, the number of employed persons increased by 2 million in Germany (roughly 7 percent of employment). This spurt in employment was unprecedented in the history of West Germany since 1960 and accordingly, references to Eurosclerosis should not be overplayed.

The main result of this paper is that a higher share of temporary work leads to an increase of the wages accruing to permanent workers. How did Bentolila and Dolado build their argument? To begin with theory, they extend the by now standard insider-outsider model by splitting employed persons into two groups, the permanent employees which represent the incumbent work-force in the sense of Lindbeck and Snower, and the temporary workforce who have the characteristic of belonging to the outsiders. More specifically, the effect of a higher proportion of temporary employment on insider wages stems from three sources, namely a buffer effect, a bargaining effect and a discipline effect. The overall effect of the share of temporary employment on wages is ambiguous, although the authors argue convincingly that the buffer effect may outweigh the bargaining effect. I am somewhat concerned about robustness of this theory: the Cobb-Douglas production function used by the authors implies by construction that the elasticity of substitution between various types of labour equals unity. As a consequence, the share of income of each type of labour among total labour income must remain constant. This hypothesis is at odds with many empirical studies. Moreover, the wage rate for temporary workers is determined by the production function so that wage determination for temporary workers is not modelled. An explicit discussion of this issue might change the results. For instance, the current formulation does not allow for the fact that a major fall in wages for temporary workers leads the firm to employ considerably more temporary workers (with the current technology, their marginal productivity decreases rapidly).

The evidence provided by the authors should not be overplayed, either. First, as indicated by the authors themselves, sharp increases in the share of temporary employment only occur in France and Spain. In the other countries, we observe a small decline in the share of temporary employment. Similarly, the view that wage setting in Europe is dominated 
by insiders should not be generalized. Estimates by the authors for Spain result in an insider weight of 0.11 . The same value holds for the $\mathrm{UK}$, while estimates for Sweden conclude with a figure of 0.04. Thus, the insider weight is anything but overwhelmingly impressive.

On the whole, I find that the evidence provided for Spain is convincing but should not be generalized to other countries without further analysis. Indeed, the description of the Spanish labour market and its institutional regulations, such as the extremely high severance payments, makes the story much more plausible for Spain than for other countries. Different effects may be at work in the other countries. For instance, in Germany, the main consequence of the higher flexibility associated with temporary work was an improved screening of newly hired workers by the firms.

\section{Christopher Pissarides}

London School of Economics and Political Science

The paper by Bentolila and Dolado is informative and contains lessons for labour market policies in other countries. The Spanish labour market is one of the least flexible labour markets in Europe. The regulations introduced in the 1970s make it very difficult for employers to shed labour. Inevitably, this has made trade unions more aggressive and companies more reluctant to create jobs. Spain's high and long-duration unemployment must have something to do with labour market regulation.

The Spanish authorities have tried to deal with the problem by introducing fixed-duration contracts which can be renewed for a limited number of years. Bentolila and Dolado document the benefits and costs of this new regulation, and their analysis supports the view that when labour market flexibility is impaired by one set of regulations, attempts to restore it by introducing another set of regulations might actually make things worse.

The legislation that introduced fixed-duration contracts came into effect in 1984. Today, about one-third of employees have fixed-duration contracts. Most of the fixed-duration contracts are held by women and young workers and they are in services. Wage determination, however, is dominated by the workers who hold the regular and secure jobs. Bentolila and Dolado list three implications for wage determination from the introduction of fixed-duration contracts: first, workers on fixed-duration contracts act as a buffer for permanent employees; second, permanent employees have more 'secondary' workers to harass in the event of dissatisfaction; but third, the firm might use temporary workers as replacement for permanent employees in the event of a strike. To these I 
would add a factor that works against the high-wage effects emphasised by Bentolila and Dolado. The advent of more temporary contracts outside the firm has made the possession of a regular contract inside it more valuable and so has reduced the attractiveness of outside opportunities for regular employees.

Bentilila and Dolado test their view that the wages of permanent employees have increased as a result of the advent of temporary employees by running wage equations that include, in addition to the long list of variables identified in other studies, the fraction of temporary workers in the firm. They find that this fraction exerts a strong upward pressure on wages. They conclude that a large part of the rise in the wages of permanent employees in the late 1980s and early 1990s is due to the increase in temporary employment.

A number of issues related both to the modelling of wage determination and to the empirical testing can be raised. In the modelling, Bentolila and Dolado argue that the fraction of temporary workers influences the share of the net surplus created by employment that goes to permanent employees. This, however, is only a conjecture which cannot really be tested empirically. Indeed, alternative formulations of the bargaining game may yield the same equation to be estimated but allow for different interpretation of the estimates.

In the empirical work there is a host of issues that is swept under the aggregation carpet. Thus, the fact that permanent employees are mainly men and temporary ones mainly women is not used in the estimation: if female wage determination differs from male, as found by several studies, the results that they find and attribute to the different kind of contract may be biased. Second, most permanent contracts are in services and most permanent ones in manufacturing. Their data come from manufacturing establishments, so inferences made about the implications of temporary contracts for the whole economy may not be correct. Third, my conjecture that the introduction of temporary contracts worsens the permanent employees' outside opportunities requires that the fraction of employees on temporary contracts outside the firm be entered in the estimated equations with negative coefficient. Finally, as the authors argue, the introduction of temporary contracts has had other implications for the labour market and these may have had feedbacks on wage determination. An interesting line to pursue is the effect that temporary contracts have had on capital accumulation and skill acquisition. Although skill acquisition is not mentioned, it is noted that the capital/labour ratio has declined after the introduction of temporary contracts. The implications of this for growth and secular wage determination might well turn out to be as important as the implications for short-run wage determination. 


\section{General discussion}

A number of panel members wondered why trade unions in Spain were not favourable to the expansion of temporary contracts, even though their initial position was more positive. The explanation provided by the authors assumes that the unions are rather myopic and could not foresee that their own position would come under threat. Paul Seabright was not satisfied with such short-sightedness on behalf of unions; he suggested that a simple analogy between union and firm competition helps a great deal to understand why temporary contracts may backfire against permanent workers: a union can be seen as acting in the labour market in the same way as a Stackelberg (dominant) firm in a product market. In the same way that there is no dominant firm which can expect that by raising its price it will reduce the market share of the fringe, there is presumably no union which can expect to exercise its market power and maintain employment. Xavier Vives was less bothered by the assumption of myopic behaviour and suggested that the apparent opposition of unions could be plain rhetoric aimed at preparing some cheap concessions in the context of a wider negotiation.

Some technical points were also raised. John Black wondered about the treatment of those workers on contracts that are both part time and temporary. Samuel Bentolila replied that these were very few and had been excluded. Vives warned against excessive generalization about the Spanish labor market given that the sample includes only private firms and that public employment in Spain is still large. Bentolila acknowledged this but indicated that, if anything, the effect of temporary workers on insiders' wages should be stronger in the public sector. Indeed, the tenure of permanent workers in the public sector is even more secure than in the private sector. Charles Wyplosz suggested that at least for France, different worker characteristics among the permanent and temporary workers should be controlled for, given that wages settlements for female workers in services differ greatly from those observed for male workers in manufacturing. Jürgen von Hagen added that the analysis did not apply well to Germany; he reported that the main channel through which flexibility is introduced in Germany is sub-contracting to foreign firms which are not subject to the same labour laws.

Alan Winters was worried that the screening effect associated with temporary work was not taken into account. This may explain in part why wages for temporary workers are lower than those for tenured workers. According to Bentolila, the probability that a temporary worker will become permanent at the end of the contractual period is however rather low, around $15 \%$. Accordingly, the incentive to invest in human capital that is specific to the firms is rather weak for temporary workers, and the 
screening effect may be limited. Vittorio Grilli suggested, however, that the presence of temporary workers did also provide firms with a benchmark against which permanent workers could be evaluated. This should reduce their market power.

\section{Appendix A. the insider-outsider model with two types of labour ${ }^{21}$}

\section{A1. The firm}

We consider a firm which employs two types of workers, permanent and temporary, which need not be equally productive. Some degree of substitution is allowed for between these two types, since temporary workers can be used for regular activities. To simplify matters, we assume that production is Cobb-Douglas:

$$
Y=\tilde{A} N_{p}^{\alpha} N_{T}^{\gamma} \quad \alpha+\gamma<1
$$

where $Y$ is output, $N_{p}$ permanent employment, $N_{T}$ temporary employment, and $\tilde{A}$ a technical progress coefficient possibly including other factors of production. Using the marginal rate of substitution (MRS) between both types of labour, (AI) can be written as

$$
Y=A\left(W_{p} / W_{T}\right)^{\gamma} N_{p}^{\alpha+\gamma}
$$

where $A=\tilde{A}(\gamma / \alpha)^{\gamma}$, and $W_{p}$ and $W_{T}$ are the wage rates for each type of worker.

The demand for the firm's product depends negatively on its own product's price, positively on aggregate demand in the economy, and is subject to random shocks, whose value is revealed only after the wage bargain has taken place. As a result, the expectation of the firm's desired level of permanent employment will depend, among other things, positively on the expected level of demand, and negatively on permanent employees' wages. The firm faces an isoelastic demand curve given by

$$
Y=\varepsilon P^{-\eta} Y_{d} \quad \eta>1
$$

where $P$ is the price of output, $Y_{d}$ a demand index, and $\varepsilon$ a random variable known after wage bargaining has taken place. The firm maximizes profits, defined as:

$$
\pi=P Y-W_{p} N_{p}(1+\gamma / \alpha)
$$

\footnotetext{
${ }^{21}$ This closely follows Layard et aL (1991), Chapter 2, and is explained in full detail in Dolado and Bentolila (1999).
} 
where the following MRS relation between $N_{\phi}$ and $N_{T}$ has been used: $W_{p} N_{p}+W_{T} N_{T}=W_{p} N_{p}(1+\gamma / \alpha)$. From the first-order condition of the maximization of (A4) subject to (A2) and (A3), expected maximum profits are given by

$\pi^{e}=(1-k(\alpha+\gamma))(\alpha k)^{-1} W_{p} N_{p}$

where $k(=1-1 / \eta)$ is the degree of market competition and $N_{p}^{e}$ is the expected optimal level of permanent employment, expressed as:

$N_{p}^{e}=\left(W_{p}^{1-\gamma} W_{T}^{\gamma} / \alpha k A P^{e}\right)^{-(1 / 1-(\alpha+\gamma) k)}$

\section{A2. The union}

The union's objective is assumed to be:

$$
V_{p}=S_{p} W_{p}+\left(1-S_{p}\right) W_{p}^{a}
$$

where $S_{p}$ is the survival probability of permanent employees and $W_{p}^{a}$ the expected income of a laid-off worker, given by

$$
W_{p}^{a}=(1-\varphi(u)) \bar{W}^{e}+\varphi(u) B=\bar{W}^{e}[1-\varphi(u)(1-b)] \quad \varphi^{\prime}>0
$$

where $\varphi(u)$ is the probability of unemployment, $\bar{W}^{e}$ the expected outside wage, $B$ the unemployment benefit, and $b\left(=B / \bar{W}^{e}\right)$ the expected benefit replacement ratio.

Denoting by $M$ the employment target of the union, the survival probability can be written as

$$
\begin{aligned}
S_{p}=\operatorname{prob}\left[N_{p} \geq M\right]+E\left(N_{p} / M \mid N_{p}<M\right) \operatorname{prob}\left[N_{p}>M\right] & \\
& =S_{p 1}\left(M / N_{p}^{e}\right)=S_{p 2}\left(W_{p}\right)
\end{aligned}
$$

where $S_{p 1}^{\prime}, S_{p 2}^{\prime}<0$. The absolute values of the elasticities of $S_{p}$ with respect to $M / N_{p}^{e}$ and $W_{p}$ will be respectively denoted as $\left|e_{S N}\right|$ and $\left|e_{S W}\right|$.

\section{A3. The Nash bargain}

The parties maximise the standard Nash maximand with status quo points $\bar{\pi}=0$ and $\bar{V}_{p}=W_{p}^{a}$, i.e.

$\Omega=\left[S_{p}\left(W_{p}-W_{p}^{a}\right)\right]^{\beta} \pi^{e}$

where $\beta$ measures workers' relative bargaining power, which is itself a function of a set of variables pertaining to the financial situation of the firm (liquidity, debt, profits) denoted by $f$, and the proportion of 
temporary workers $\phi$. Assuming linearity we get

$\beta=c_{3} f+\delta \phi$

where $c_{3}>0$ and the sign of $\delta$ is ambiguous (see text). Differentiating $\Omega$ (in logs) with respect to $W_{p}$ and taking into account that $\left|e_{S W}\right|=\left|e_{S N}\right|\left|e_{N W}\right|$, the following expression for the mark-up of the wage over the alternative income is obtained:

$\left(W_{p}-W_{p}^{a}\right) / W_{p}=(1-k(\alpha+\gamma)) /\left(\left|e_{S N}\right|(1-\gamma k)+(k \alpha / \beta)\right)$

\section{A4. Empirical formulation}

On the basis of the dependence of $\left|e_{S N}\right|$ on $\left(M / N_{p}^{e}\right)$ and (A5), we loglinearise (A7) to derive the impact of the relevant variables on firm-level wages. Taking the lower-case letters, $a, m, w, p$, and $n$ to represent logs, we have

$$
\begin{aligned}
w_{p}= & \text { constant }+\lambda\left[a+p^{e}+\gamma\left(w_{p}-w_{T}\right)-(1-(\alpha+\gamma)) m\right] \\
& +(1-\lambda)\left[\bar{w}^{e}-c_{1} u+c_{2} b\right]+c_{3} \beta+c_{4} k
\end{aligned}
$$

where $0 \leq \lambda \leq 1$, given the homogeneity of $W_{p}$ in $\bar{W}^{e}$ and $M / N_{p}^{e}$ (see Layard et al, 1991, p. 183). After substituting $a$ out using (A2), assuming that $m=n_{p,-1}$, and exploiting the relation $n_{p}-n \simeq \log (1-\phi) \simeq-\phi$, we can express the first bracketed term in (A8) as:

$\left[(p+y-n)^{e}+\phi^{e}+(1-(\alpha+\gamma)) \Delta n_{p}^{e}\right]$

Also, our wage data correspond to the average labour cost per employee and not to the wage earned by permanent workers. But the average wage is given by $W=\left(W_{T} N_{T}+W_{p} N_{p}\right) / N=\left(W_{p} N_{p}\right)(1+\gamma \alpha) / N$, which in logs can be approximated by

$w=w_{p}-\phi+$ constant

Thus given (A9), (A10), and (A6), we can write the log-linear approximation of (A7) in terms of the average wage:

$$
\begin{aligned}
w= & \text { constant }+\lambda\left[(p+y-n)^{e}+(1-(\alpha+\gamma)) \Delta n_{p}^{e}\right] \\
& +(1-\lambda)\left[\bar{w}^{e}-c_{1} u+\sigma_{2} b\right]+o_{3} f+(\delta-(1-\lambda)) \phi^{e}+c_{4} k
\end{aligned}
$$

If the bargaining unit also included a proportion $\tau$ of the temporary workers in their employment target (e.g. those expected to become permanent employees), i.e. $M=N_{p_{1}-1}+\tau N_{T,-1}$, then, assuming that the 
product $\tau \phi_{-1}$ is small, we would have, in logs, $m \simeq n_{p,-1}+\tau \tilde{\phi}_{-1}$, where $\tilde{\phi}_{-1}=\phi_{-1}\left(1 /\left(1-\phi_{-1}\right)\right)$. Thus $\tilde{\phi}_{-1}$ should be added to (A11). Note that, from (A10) and (A11), the (semi) elasticity of $w_{p}$ with respect to $\phi$ is given by $(\delta+\lambda)$. (It turns out that $\tilde{\phi}_{-1}$ never enters significantly in the regressions reported in Tables 6 and 7).

When the lagged dependent variable is entered in the equation, the expression to estimate is:

$$
\begin{aligned}
& w_{i t}=a_{i}+a_{1} w_{i t-1}+a_{2}(p+y-n)_{i t}+a_{3} \Delta n_{p i t}+a_{4} \bar{w}_{t}+a_{5} u_{t}+a_{6} b_{t} \\
& +a_{7} k_{j t}+a_{8} f_{i t}+a_{9} \phi_{i t}+a_{10} \tilde{\phi}_{i t-1}+\varepsilon_{i t}
\end{aligned}
$$

where $a_{i}$ denoptes a firm-specific fixed effect.

The hypotheses of interest $\left(H_{0}\right)$ are the following: homogeneity in inside and outside factors $(h)$; a full buffer effect (be); and no bargaining effect ( $n b)$. They can be represented as follows:

$$
H_{0}^{h}: a_{1}+a_{2}+a_{4}=1 ; \quad H_{0}^{b e}: a_{10}=0 ; \quad H_{0}^{n b}: a_{4}+a_{9}=0 .
$$

\section{A5. Generalisation of the model to a CES production function}

The production function is generalised to a CES, with elasticity of substitution greater than or equal to unity, that is:

$$
Y=\tilde{A}\left[N_{p}^{\rho}+m N_{T}^{\rho}\right]^{\nu / \rho} \quad 0 \leq \rho \leq 1
$$

where $\nu(=\alpha+\gamma)$ is the returns-to-scale parameter, $\rho$ is the substitution parameter such that the elasticity of substitution, $\sigma$, is equal to $(1-\rho)^{-1}$, and $m$ is the relative efficiency of temporary workers with respect to permanent workers.

Then, after some tedious algebra, we find a similar wage equation to (A11), except that (A9) and (A10) now become:

$$
\begin{aligned}
& {\left[(p+y-n)^{e}+\phi^{e}-g\left(\phi^{e}\right)+(1-\nu) \Delta n_{p}^{e}\right]} \\
& w=w_{p}-\phi+g(\phi)+\text { constant }
\end{aligned}
$$

with $g(\phi)=\log \left(1+m(\phi /(1-\phi))^{\rho}\right)$, a function which is non-differentiable at $\phi=0$.

Thus, a rise of one percentage point in $\phi$ will have a total effect on $w$ equal to $-(1-\lambda-\delta)+(1-\lambda) \Delta g(\phi)$. Taking $\phi=0.22, \sigma=4$ (i.e. $\rho=0.75), m=0.85, \lambda=0.11$, and the total estimated value of -0.64 , the joint buffer-bargaining effect $(\lambda+\delta)$ of a rise in $\phi$ from 0.22 to 0.23 , is 0.34 instead of 0.35 . If $\phi$ rises from 0.22 to 0.32 , the corresponding effect 
is 2.52 instead of 3.5. The remaining calculations appearing in the main text are performed in the same fashion.

\section{Appendix B. Definitions and further empirical results}

\section{B1. Definitions for Section 4}

(a) Definitions of variables (Source: Central de Balances del Banco de España, unless noted otherwise)

Employment: Average number of employees over the year. For fixed-term work, the number of employees is multiplied by their number of weeks of work and divided by 52 . Wages. Total labour costs divided by employment. Productivity: Sales divided by employment. Concentration ratio: Sectoral share of firms with the 5 largest market shares (Source: Encuesta Industrial). Profits: After-tax accounting profits divided by employment. Interest rate: Financial costs divided by total debt.

\section{(b) Sectoral classification and number of firms}

Automobiles, 38; Mineral extraction, 29; Construction materials, 90; Chemicals, 174; Agricultural and industrial machinery, 217; Office machinery, electric materials, and economics, 74; Ship-, train-, and plane-building, 16; Precision and optical instruments, 4; Food, beverages, and tobacco, 180; Textiles, leather, and shoes, 161; Wood, pulp, and paper, 108; Rubber and plastics, 60; Other manufacturing, 16.

\section{B2. Estimation method and further empirical results for Section 4}

\section{(a) Estimation method}

Equation (A12) is estimated using the generalized method of moments (GMM) with an optimal weights technique due to Arellano and Bond (1991) (with their DPD program, see Arellano and Bond, 1988). After first-differencing to eliminate fixed effects, under the assumption that $\varepsilon$ is white noise, the error has an MA(1) structure and is correlated with the lagged dependent variable, requiring instruments (dated at $t-2$ ) for variables not assumed to be exogenous. The assumption of no serial correlation of the errors in levels is tested for by the $m_{2}$ statistic, asymptotically distributed as $N(0,1)$. The (over)identifying restrictions test, $S_{\mathrm{IV}}$, is asymptotically distributed as $\chi^{2}(m-k)$, with $m$ the number of instruments and $k$ that of regressors.

Variables $w_{-1}, p+n-y, \Delta n_{p}$, and $\phi$ are treated as endogenous, whereas the remaining variables with firm or sectoral variation are lagged one period and treated as exogenous. An extended set of 52 instruments is used, consisting of all lags of those four variables from $t-2$ back, plus a 
constant, the exogenous variables in the equation, and $r$ and $m l d$ lagged once. The reduced instrument set of 35 instruments was selected from the most significant regressors in the reduced form equations for the instrumented variables.

\section{(b) Further empirical results}

(b.1) Hours. We should control for hours per worker if bargaining is over hourly wages and the number of hours, rather than over the average wage per employee as assumed in the model. If changes in hours raise wages and measured productivity, this omission would cause an upward bias in $\gamma$. On top of his, by raising procyclicality, it could generate a higher unemployment effect. Data on hours are however available only at the sectoral level. When included in the preferred equation, this variable had an insignificant coefficient of 0.03 (tratio: 0.3 ) and the remaining coefficients hardly changed in size or significance.

(b.2) Within sample parameter stability tests. These tests were carried out for the coefficients of $(p+y-n)$ and $\Delta n_{p}$ over the sub-samples 1985-86 and $1987-88$, by adding to the preferred equation (column 1 of Table 6 ) both variables intersected with a dummy variable taking a value of unity in 1987-88. The estimated changes were insignificant: -0.03 ( $t$-ratio: 1.1 ) for $\lambda$, and -0.01 ( $t$-ratio: 0.8 ) for $\Delta n_{p}$. In 1987-88 labour productivity in manufacturing fell by 2 percentage points; so the reduction in $\lambda$, although insignificant, offers weak evidence of an asymmetry in wage adjustment: workers are happy to take a wage hike when productivity is high, but less willing to take a cut when it is low. A stability test for the coefficient on $\phi$ yields an increase of 0.09 ( $t$-ratio: 2.39), significant but small. Since there is no strong sign of instability in the insider weight, we interpret this shift as an increase in $\delta$, i.e. a rise in the strength of the harassment effect relative to the discipline effect, which is compatible with he observed resurgence of a positive wage drift.

(b.3) Sectoral heterogeneity of $\lambda$ : We find a wide range of values of $\lambda$ across sectors. This confirms the results of Draper (1993), who finds, in equivalent sectoral regressions for Spanish manufacturing, that insider weights are positively related to the degrees of competition and openness to foreign trade. To pursue this idea, we computed the rank correlation coefficient between sectoral nominal labour productivity growth in 1984 89 and our estimates of $\lambda$, obtaining a value of 0.63 (tratio: 2.9). This relation may hinder employment growth: if low productivity industries are mainly affected by the alternative wage, whereas productivity gains in the more dynamic industries feed through partially to wages, the process of employment reallocation after sector-specific shocks may be curtailed, since job destruction in the former industries would not be matched by job creation in the latter. 


\begin{tabular}{|c|c|c|c|c|c|c|}
\hline & \multirow[b]{2}{*}{ Mean } & \multirow{2}{*}{$\begin{array}{l}\text { Std. } \\
\text { dev. }\end{array}$} & \multirow[b]{2}{*}{ Max. } & \multirow[b]{2}{*}{ Min. } & \multicolumn{2}{|c|}{$\begin{array}{l}\text { Avg. annual } \\
\text { growth (\%) }\end{array}$} \\
\hline & & & & & Sample & Manuf. \\
\hline \multicolumn{7}{|l|}{ Firm-level data: ${ }^{(b)}$} \\
\hline Total employment & 315 & 1,004 & 21,718 & 2 & -0.9 & 0.2 \\
\hline Permanent employment & 300 & 997 & 21,694 & 1 & -1.9 & - \\
\hline Temporary employment & 15 & 43 & 914 & 0 & 22.0 & - \\
\hline Labour cost $\mathrm{p} / \mathrm{employee} \mathrm{e}^{(\mathrm{c})}$ & 21 & 8 & 119 & 3 & 9.6 & 9.0 \\
\hline Sales $^{(d)}$ & 41 & 164 & 4,619 & 10 & 14.0 & 12.4 \\
\hline Ratios (\%): & & & & & & \\
\hline Temporary employment & 6.6 & 12.9 & 94.1 & 0.0 & 4.7 & \\
\hline Concentration index & 19.5 & 12.2 & 99.2 & 5.5 & 0.5 & \\
\hline Medium/long term debt & 14.0 & 19.0 & 99.8 & 0.0 & 52.4 & \\
\hline Economy-wide data: & Mean & $\begin{array}{c}\text { Growth } \\
\text { rate } \\
(\%)\end{array}$ & & & & \\
\hline Labour $\operatorname{cost}^{(e)}$ & 17.0 & 9.0 & & & & \\
\hline Unemployment rate & 20.0 & 2.2 & & & & \\
\hline Replacement ratio & 54.0 & -3.0 & & & & \\
\hline
\end{tabular}

Notes:
(a) 1983-88 data unless otherwise noted. Money figures at 1991 peseta-dollar exchange rates.
(b) Except the last column, which corresponds to the manufacturing sector.
(c) In thousand dollars.
(d) In million dollars.
(e) Average labour cost in manufacturing and services in thousand dollars.

(b.4) Skill composition revisited: Our interpretation of the $\delta$ coefficient may be mistaken because of the lack of control for skill levels. Since the skill composition affects the average wage, if the proportion of fixed-term contracts is correlated with skill levels and this variable is not included in the regression, the estimated coefficient on $\phi$ would be biased. Lacking the information on the skill composition within firms, we have calculated a skill index defined as the proportion of workers in unskilled occupations in each sector. The correlation between the sectoral rankings of the change in the skill index and the change in the proportion of fixed-term employment, from $1987 \mathrm{Q} 2$ to $1991 \mathrm{Q} 2$, is 0.12 (tratio $=0.4$ ). In other words, there is no clear correlation between skills and fixed-term contracts. 


\begin{tabular}{|c|c|c|}
\hline & tratio & $\chi^{2}$ (d.f.) \\
\hline $\begin{array}{l}\text { Long-run homogeneity of inside and outside factors } \\
\text { Equality of coefficient on } \phi \text { and outsider weight } \\
\text { Non-representation of temporary employees } \\
\text { Significance of coefficient on the proportion of long-term } \\
\text { unemployed } \\
\text { Joint significance of } 13 \text { sectoral dummies } \\
\text { (a) alone } \\
\text { (b) intersected with time dummies } \\
\text { (c) intersected with lagged wages and change in permanent } \\
\text { employment } \\
\text { (d) intersected with productivity } \\
\text { (e) intersected with proportion of temporary empl. } \\
\text { Rank correlation between the industrial strife index and the } \\
\text { estimated sectoral } \delta \text { coefficients }\end{array}$ & $\begin{array}{l}0.4 \\
3.3 \\
1.1 \\
\\
0.3\end{array}$ & $\begin{array}{l}22.2(13) \\
63.2(52) \\
\\
18.4(24) \\
18.6(12) \\
20.7(12)\end{array}$ \\
\hline
\end{tabular}

B3. Definitions and estimation method for Section 5

(a) Definitions of sectoral variables (Source. Cronos database, Eurostat). Employment. Number of employees. Wages. Labour cost divided by number of employees. Productivity: Value added at constant prices divided by number of employees. Price: Value added deflator $(1985=100)$. Temporary and part-time ratios. Temporary and part-time employees, respectively, divided by number of employees.

\section{(b) Sectoral classification (2-digit NACE-CLIO codes)}

Metals mineral extraction (21-22); Non-metals mineral extraction (23-24); Chemicals (25-26); Metal products except machinery and transport equipment (31); Agricultural and industrial machinery (32); Office machinery, electronic materials and precision instruments $(33,37)$; Electric materials (34); Ship-, train-, and plane-building (35-36); Food, beverages, and tobacco (412-42); Textiles, leather, and shoes (43-45); Wood, pulp, and paper (47); Rubber and plastics (48).

\section{(c) Estimation method}

The method is fixed-effects in a pooled regression, rather than GMM in differences as in Section 4, because the number of industries (13) is not large relative to the number of years (8). The instrumented variables are as in Section 4, except for the lagged dependent variable, which is predetermined under the assumption that the error term is serially uncorrelated. This hypothesis is tested for by means of the $\operatorname{AR}(1)$ test, asymptotically distributed as $\chi^{2}(1)$. The 24 instrumental variables are 
$(p+y-n)_{j t-1}, n_{j t-1}, n_{j t-2}, y_{j t-1}, p_{j t-1}$, and $\phi_{j t-1}$ (where $j$ denotes sectors), the exogenous and predetermined variables and the 13 industry dummies, whose validity is tested by the $S_{\mathrm{IV}}$ test, asymptotically distributed as $\chi^{2}(7)$.

\section{References}

Alba, A. (1991). 'Fixed-term Employment Contracts in Spain: Labor Market Flexibility or Segmentation?', Universidad Carlos III de Madrid, Working paper 91-29.

Andrés, J. and J. Garcíia (1993). 'Factores Determinantes de los Salarios: Evidencia para la Industria Española', in J. Dolado, C. Martín and L.R. Romero (eds.), La Industria y el Comportamiento de las Empresas Españolas: Ensayos en Homenaje a Gonzalo Malo, Alianza Editorial, Madrid.

Arellano, M. and S. Bond (1988). 'Dynamic Panel Data estimation Using DPD - A Guide for Users', Oxford University, mimeo.

- (1991). 'Some Tests of Specification for Panel Data: Monte Carlo Evidence and an Application' to Employment Equations', Review of Economic Studies.

Bentolila, S. and G. Saint-Paul (1992). 'The Macroeconomic Impact of Flexible Labor Contracts, with an Application to Spain', European Economic Review.

Bertola, G. (1990). 'Job Security, Employment and Wages', European Economic Review.

Bielenski, H. and E. Köhler (1992). 'Nuevas Formas de Trabajo y Actividad. Primeros Resultados de una Encuesta Representativa de Empresas', addenda to the Spanish version of G. Rodgers and J. Rogers (eds.) (1989) (El Trabajo Precario en la Regulación del Mercado Laboral Ministerio de Trabajo y Seguridad Social, Madrid).

Blanchard, O. and L. Summers (1986). 'Hysteresis and the European Unemployment Problem', in S. Fischer (ed.), NBER Macroeconomics Annual 1986, The MTT Press, Cambridge, MA.

Blanchflower, D., A. Oswald and M. Garrett (1990). 'Insider Power in Wage Determination', Economica.

Brunello, G. and S. Wadhwani (1989). 'The Determinants of Wage Flexibility in Japan: Some Lessons from a Comparison with the UK Using Micro Data', London School of Economics, Centre for Labour Economics, Discussion Paper No. 362.

Büchtemann, C. and S. Quack (1989). "'Bridges" or "Traps"? Atypical Employment in the Federal Republic of Germany', in G. Rodgers and J. Rodgers (eds.), Precarious Jobs in Labour Market Regulation: the Growth of Atypical Employment in Western Europe, International Labour Organization, Geneva.

Burda, M. and C. Wyplosz (1994). 'Gross Worker and Job Flows in Europe', mimeo, INSEAD. Eumpean Economic Review (forthcoming).

Commission of the European Communities (1990). Employment in Europe 1990, Luxembourg. (19930. Employment in Europe, 1993, Luxembourg.

Dolado, J. and S. Bentolila (1993). 'Who are the Insiders? Wage Setting in Spanish Manufacturing Firms', CEPR Discussion Paper No. 754.

Draper, M. (1993). 'Indiciación Salarial y Empleo: Un Análisis Desagregado para el Caso Español', Moneda y Crédito.

Emerson, M. (1988). 'Regulation or Deregulation of the Labour Market: Policy Regimes for the Recruitment and Dismissal of Employees in the Industrialized Countries', European Ecomomic Review.

Eurostat (1992). Labour Force Survey, Luxembourg.

Franz, W. and R.J. Gordon (1993). 'German and American Wage and Price Dynamics', European Economic Review.

Garcia Perea, P. and R. Gómez (1993). 'Elaboración de Series Homogéneas de Costes Laborales Unitarios', Banco de España, Internal document EC/1993/29.

Hemando, I. and J. Vallés (1993). 'Productividad, Estructura de Mercado y Situación Financiera', Banco de España, Working Paper No. 9227.

Holmlund, B. and J. Zetterberg (1989). 'Insider Effects in Wage Determination: Evidence from Five Countries', Uppsala University, mimeo.

Jimeno, J. and L. Toharia (1992). 'Productivity and Wage Effects of Fixed-term Employment: Evidence from Spain', FEDEA, Working Paper No. 9211.

- (1993a). 'The Effects of Fixed-term Employment on Wages: Theory and Evidence from Spain', Investigaciones Economicas.

(1993b). 'The Productivity Effects of Fixed-Term Employment Contracts: Are Temporary Workers Less Productive than Permanent Workers?', FEDEA, Working Paper No. 9304. 
(1994). Unemployment and Labour Market Flexibility: The Case of Spain, International Labour Organisation, Geneva (forthcoming).

Layard, R, S. Nickell and R. Jackman (1991). Unemployment, Oxford University Press, Oxford.

Lindbeck, A and D. Snower (1988a). 'Cooperation, Harassment, and Involuntary Unemployment: An Insider-Outsider Approach', American Economic Review. MA.

(1988b). The Insider-Outsider Theory of Employment and Unemployment, The MIT Press, Boston,

Manning, A. (1992). 'Wage Bargaining and the Phillips Curve: The Identification and Specification of Aggregate Wage Equations', Centre for Economic Performance, Discussion Paper No. 62.

Nickell, S. (1987). 'Why is Wage Inflation in Britain so High?', Oxford Bulletin of Economics and Statistics.

Nickell, S. and M. Andrews (1983). 'Unions, Real Wages and Employment in Britain, 1951-79', Oxford Economic Papers.

Nickell, S. and P. Kong (1992). 'An Investigation into the Power of Insiders in Wage Determination', European Economic Review.

Nickell, S. and S. Wadhwani (1990). 'Insider Forces and Wage Determination', The Economic Joumal. (1991). 'Employment Determination in British Industry: Investigations using Micro-Data', Review of Economic Studies.

Organization for Economic Cooperation and Development (OECD) (1993). Employment Outlook 1993, Paris.

Rice, P. (1990). 'Relative Labour Costs and the Growth of Part-time Employment in British Manufacturing Industries', The Economic Journal.

Rodgers, G. and J. Rodgers (eds.) (1989). Precarious Jobs in Labour Market Regulation: the Growth of Atypical Employment in Western Europe, International Labour Organization, Geneva.

Saint-Paul, G. (1993). 'The Political Economy of Labor Market Flexibility', in O. Blanchard and S. Fischer (eds.), NBER Macroeconomics Annual 1993, The MIT Press, Cambridge (MA).

Segura, J., F. Durán, L. Toharia and S. Bentolila (1991). Análisis de la Contratación Temporal en España, Ministerio de Trabajo y Seguridad Social, Madrid.

Wadhwani, S. (1987). 'The Macroeconomic Implications of Profit Sharing: Some Empirical Evidence', The Economic Joumal 